INTERNATIONAL MONETARY FUND

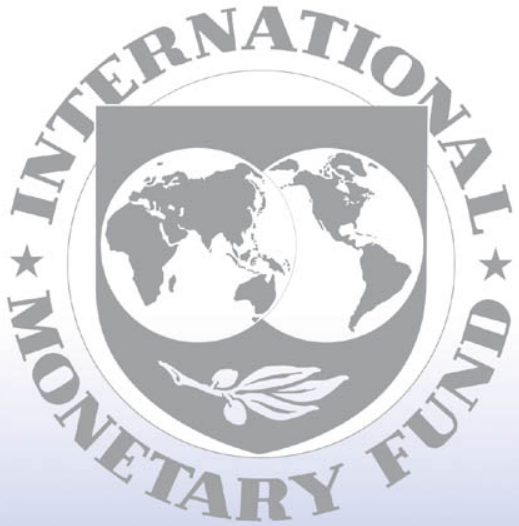

Staff

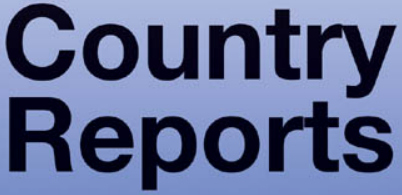




\title{
Kingdom of the Netherlands-Netherlands Antilles: Recent Developments, Selected Issues, and Statistical Appendix
}

This Recent Developments, Selected Issues, and Statistical Appendix on the Kingdom of the Netherlands-Netherlands Antilles was prepared by a staff team of the International Monetary Fund as background documentation for the periodic consultation with the member country. It is based on the information available at the time it was completed on April 20, 2001. The views expressed in this document are those of the staff team and do not necessarily reflect the vicws of the government of the Kingdom of the Netherlands-Netherlands Antilles or the Executive Board of the IMF.

The policy of publication of staff reports and other documents by the IMF allows for the deletion of market-sensitive information.

To assist the IMF in evaluating the publication policy, reader comments are invited and may be sent by e-mail to Publicationpolicy@imf.org.

\author{
Copies of this report are available to the public from \\ International Monetary Fund - Publication Services \\ 700 19th Street, N.W. - Washington, D.C. 20431 \\ Telephone: (202) 6237430 - Telefax: (202) 6237201 \\ E-mail: publications@imf.org • Internet: http://www.imf.org \\ Price: $\$ 15.00$ a copy

\section{International Monetary Fund Washington, D.C.}




\section{KINGDOM OF THE NETHERLANDS - NETHERLANDS ANTILLES}

\section{Recent Developments, Selected Issues, and Statistical Appendix}

Prepared by Gerwin Bell and Jan Kees Martijn

Approved by the European I Department

Aprit 20, 2001

Contents

Introduction.

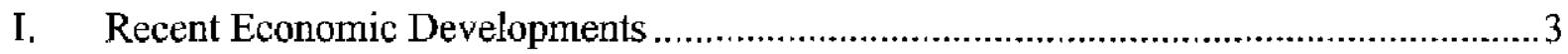

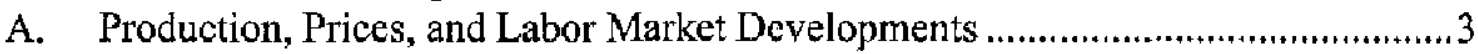

B. Public Finance ......................................................................................

C. Money, Banking, and Financial Sector ...........................................................

D. Balance of Payments ..........................................................................................

II. Adjustment Policy in the Presence of Labor Mobility, 1999-2001 .............................10

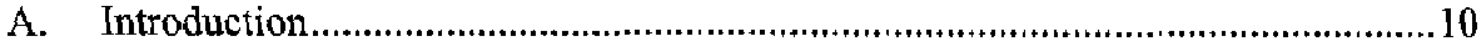

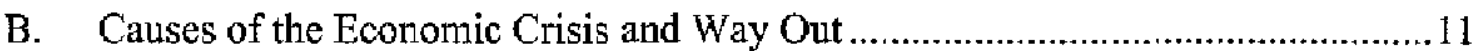

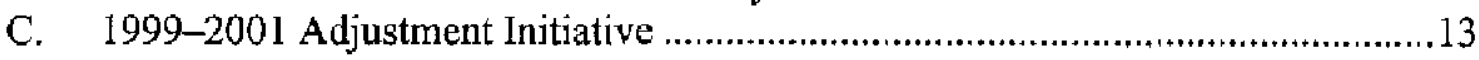

D. Outstanding Initiatives and Remaining Challenges ............................................18

III. Developments in Offshore Financial Services............................................................19

A. Some Basics on Offshore Operations .............................................................19

B. Recent Challenges for Offshore Centers........................................................20

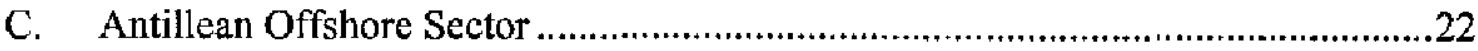

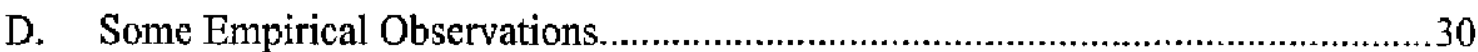

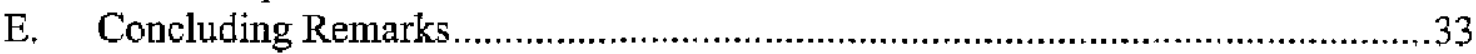

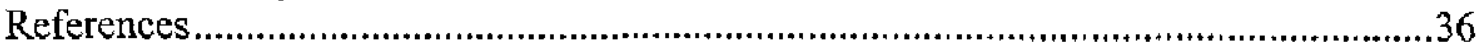

Tables

1. Main Fiscal Measures Adopted Under the 1999-2001 Adjustment Initiative ...............15

2. Main Structural Measures Adopted Under the 1999-2001 Adjustment Initiative .........17

3. Growth in BIS Reporting Bank Claims on Offshore Centers, 1986-2000 _......................24

4. Selected Indicators of Offshore Centers ..............................................................29

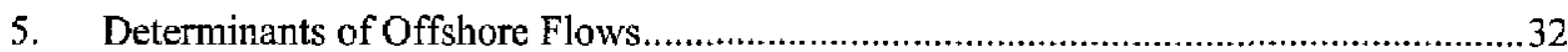

6. Determinants of Netherlands Antilles' Offshore Market Share ..................................34 
Boxes

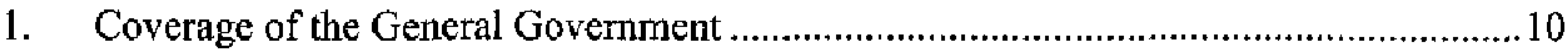

Appendices

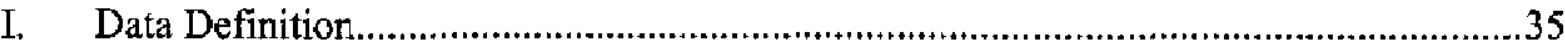

Statistical Appendix Tables

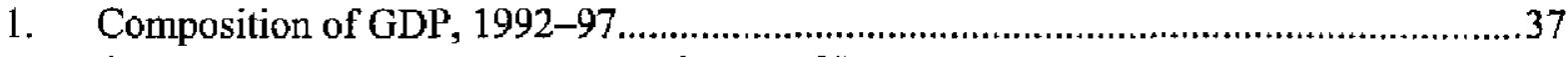

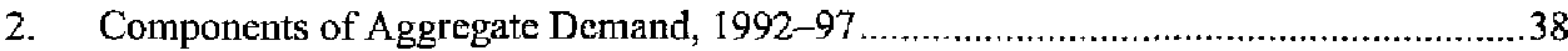

3. $\quad$ Selected Indicators of Economic Activity, 1992-2000 .........................................39

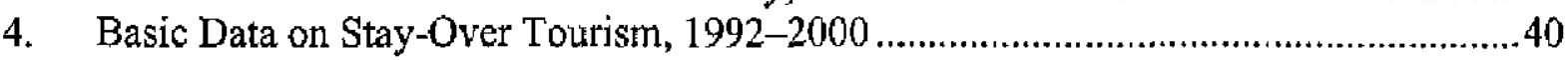

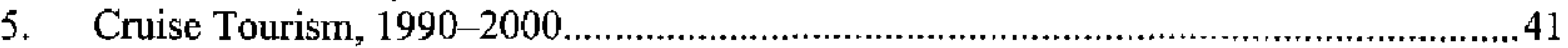

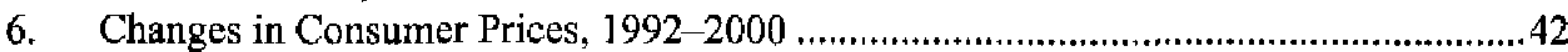

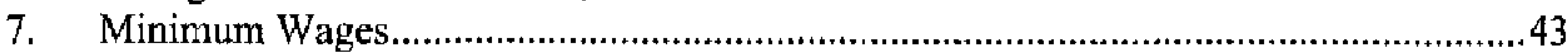

8. Employment, Unemployment, and Migration, 1990-2000 .....................................44

9. Operations of the General Government, 1996-2000 ...........................................45

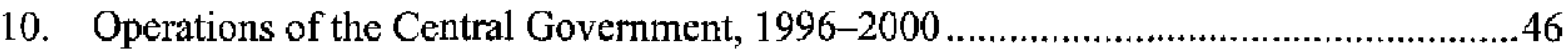

11. Operations of the Island Government of Curacao ....................................................48

12. Financing of General Government, 1996-2000 .................................................50

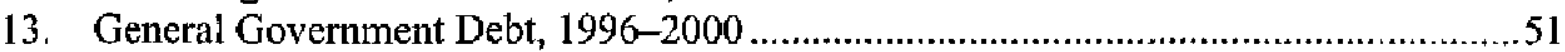

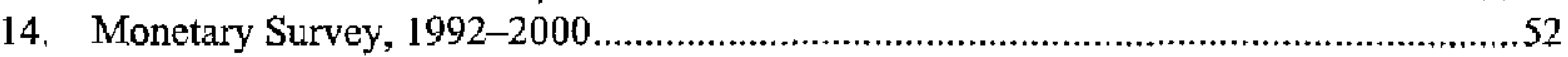

15. Commercial Banks Credit to the Private Sector, 1992-2000 ..................................53

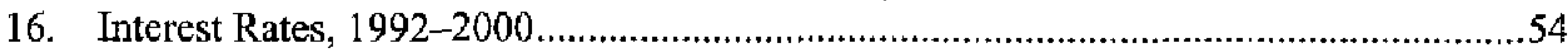

17. Structure and Performance of the Banking System, 1994 2000 .............................55

18. Nonbank Financial Intermediation: Insurance Companies, 1994-99 .......................56

19. International Financial Sector, 1994-2000 ......................................................57

20. Balance of Payments, 1996-2000 .......................................................................58

21. Current Inflows (Cash Basis), 1995-99 .................................................................59

22. Current Outflows (Cash Basis), 1995-99 ...........................................................60

23. Capital Account (Cash Basis), 1995-99 ….................................................................61

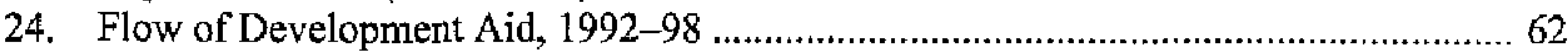

25. Multi-Year Plan Disbursements by Sectors and Authorities, 1992-98 .....................63

26. Aid from the European Development Fund, Disbursements by Sectors

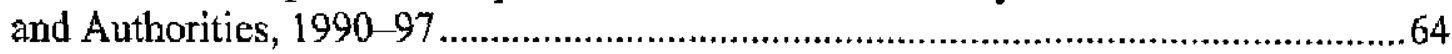

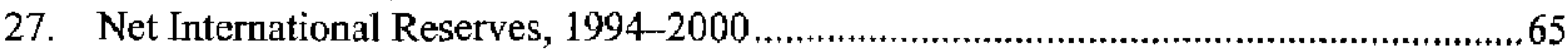




\section{INTRODUCTION}

1. The Netherlands Antilles consist of a federation of five Caribbean islands, with a population of about 200,000 inhabitants. ${ }^{1}$ It is an autonomous, but integral part of the Kingdom of the Netherlands, and its own currency, the Netherlands Antillean guilder, has been pegged to the U.S. dollar at a fixed rate since December 1971. As is typical for small island economies, the Antillean economy is undiversified, relying mainly on tourism, shipping, offshore finance, and oil refining.

2. The past decade has witnessed a progressive weakening of the economy, leading to a prolonged recession in recent years, high unemployment, and a tide of emigration. Adverse economic shocks, especially affecting the offshore sector and to a lesser extent tourism, and inadequate policy adjustment are the underlying causes. Economic developments and policies during the past two years are described in some detail in Chapter I, which refers also to the Statistical Appendix. Chapter II discusses the challenge of adjusting to adverse shocks when labor is mobile, as is the case in the Netherlands Antilles. In these circumstances, wages and the exchange rate cannot be used effectively to facilitate adjustment, and fiscal tightening alone will further induce emigration. This puts the onus of improving economic growth and job prospects on comprehensive domestic reform and policy adjustment. Against this background, Chapter II also describes the accomplishments to date under the 1999-2001 adjustment initiative and notes the remaining challenges. Chapter III reviews developments in the Antillean offshore sector and explores its prospects. Though the sector's importance for the Antillean economy has diminished, it still provides a significant contribution to value added, tax revenues, and employment. In response to heightened international scrutiny of offshore jurisdictions, the Antillean authorities have decided to step up regulation. While this has removed some of the uncertainty surrounding the sector, its prospects remain unclear.

\section{RECENT ECONOMIC DEVELOPMENTS ${ }^{2}$}

3. This chapter provides a brief review of economic developments and policies focusing on the period since the 1999 Article IV consultation.

\section{A. Production, Prices, and Labor Market Developments}

4. In 1998, the Netherlands Antilles entered a prolonged recession. While final national accounts data are only available through 1997 (SA ${ }^{3}$ Tables 1 and 2), estimates of production developments point to a cumulative contraction in real output of $6^{1 / 4}$ percent

\footnotetext{
${ }^{1}$ The five islands are Curaçao and Bonaire (the Leeward Ișlands), and Saba, St. Eustatius, and the southern part of St. Maarten (the Windward Islands).

${ }^{2}$ Prepared by Gerwin Bell and Jan Kees Martijn.

${ }^{3} \mathrm{SA}=$ Statistical Appendix.
} 
between 1997 and 2000. Particularly large declines appear to have taken place in the primary sector, construction, and public administration, reflecting both external and domestic factors as well as a decline in public sector employment. While inflation has been low, employment prospects remained poor, and large-scale emigration ensued. Recently, however, some signs of improvement in the outlook have emerged, in part as a result of progress with structural reform.

\section{Negative external shocks and inadequate policies accounted for much of the} recession. The Netherlands Antilles were adversely affected in each of its major export sectors (SA Table 3). Following the low oil prices throughout 1999, oil production and, more importantly, transshipment registered sharp declines. Shipping and port activity also declined, while the unusually high incidence of hurricanes in the Windward Islands (St. Maarten, St. Eustatius, and Saba) took its toll on the tourism sector, which has not yet fully recovered. On the policy front, fiscal imbalances were not brought under control, contributing to arrears to the pension fund and private suppliers, and an erosion of confidence.

6. The exchange rate peg to the U.S. dollar has kept underlying inflation low. In both 1998 and 1999, consumer inflation in the Antilles remained considerably below inflation in the U.S., the anchor country, notwithstanding some higher inflation in the Windward Islands after the burricanes (SA Table 6). This undoubtedly owed much to the depressed state of the economy. In 2000 , inflation accelerated sharply- to an estimated 4.7 percent, compared to 3.2 percent in the U.S. - - as the result of an increase in indirect taxes and higher oil prices.

\section{Labor market developments have remained unfavorable and emigration has} accelerated. With low inflation and a depressed economy, direct wage pressures have been largely absent. Nominal minimum wages have not been changed since 1996 (SA Table 7) and collective labor agreements were extended by 12 months in the aftermath of the hurricanes. Representative wage agreements in Curaçao, negotiated since then, point to wage increases of some cumulative 5 percent over the subsequent three years. Employment creation has been anemic (SA Table 8) and the estimated decline in the unemployment rate for Curaçao - to 14 percent in 2000 from 15.9 in 1999 , notwithstanding a large retrenchment exercise in the government--owes much to emigration to the Netherlands (SA Table 9). While providing an outlet for unemployment, free mobility to the Netherlands essentially locks the Antilles into a high wage structure in which Dutch welfare payments establish a floor and Dutch demand for skilled professionals (such as teachers and nurses) raises reservation wages. ${ }^{4}$ Moreover, surveys of employers paint a bleak picture of the employability of both the long-term unemployed and recent school graduates. Much of the

\footnotetext{
${ }^{4}$ The Island of Curaçao has been the most affected by emigration. Much of the emigration centered on the younger population, thus accelerating aging of society with considerable risk for the sustainability of the old age pension system.
} 
employment pressure in the low-skill range is being absorbed by (mostly illegal) immigrants from neighboring countries. At the same time, employers cite a continuing lack of skilled professionals, especially in the key tourism sector. In an effort to redress bottlenecks in the recruitment of needed expatriate personnel, the government bas recently liberalized the employment authorization for Dutch citizens.

8. However, there are recent signs of improvement in the economic outlook. Oil prices have recovered; tourism, especially higher value added stay-over tourism, has begun to pick up (SA Tables 4 and 5); new American chains have entered the hotel sector; the ship repair business is showing signs of recovery; and new large-scale investments have been initiated (refinery and power sector), involving an investment volume of more then US $\$ 100$ million (some 4 percent of GDP).

9. During the past two years, important structural reforms have also been implemented (see also Chapter $\mathrm{I}$ ). The Netherlands Antilles adopted an open-sky framework, abolished production monopolies and import quotas, introduced more flexible work arrangements, particularly for the tourism sector, and lifted the individual dismissal permit requirement for most sectors. Measures to promote privatization, electronic commerce, and the development of the international financial service sector were also implemented.

\section{B. Public Finance}

10. During the past decade, fiscal policy was marked by intermittent episodes of adjustment and policy drift. The budget never fully adjusted to the sharp decline in offshore tax revenues. As a result of wage drift and unsustained attempts at fiscal consolidation, the deficit rose to 4-5 percent of GDP in the mid-1990s. When a Fund staffsupported adjustment initiative in mid-1997 went off track after only a few months, an expansionary approach was pursued, but with little success owing to financing constraints. Since late 1999, a renewed program of fiscal consolidation has been underway.

\section{Budget execution in 1999 and 2000 was hampered by revenue shortfalls and} refinancing problems. Despite the implementation of major fiscal adjustment measures, the budget deficit of the general government did not decline to a sustainable level (SA Table 9). Though adjustment included the dismissal of about 20 percent of civil servants, most of the savings associated with this measure will not accrue until 2004, when severance payments expire. Progress in reducing the deficit was further hampered by tax collection problems, delays in implementing planned expenditure cuts, and emerging claims on past government guarantees. On the financing side, increased external support partly substituted for domestic financing, which became scarce as the result of the weakening economy and erosion of investor confidence. Even so, sizeable arrears accumulated to the pension fund, private suppliers, and the Dutch government.

12. At the general government level, the 1999 deficit amounted to NA f. 167 million (3.8 percent of GDP), well above the level recorded in the previous year, and exceeding 
available domestic financing. The deficit increased at both levels of government. At the central government level, a large revenue shortfall emerged when the obligation to pay sales taxes was lifted at the beginning of the year, but the turnover tax replacing it did not become effective until March (SA Table 10). The finances of the island government of Curaçao were strained by lower profit and income taxes, as a result of the economic slowdown (SA Table 11). Furthermore, during the year, confidence weakened, eroding domestic investors' willingness to refinance maturing government securities. Severe cash constraints forced the island government to compress spending on goods and services. The lack of resources eventually resulted in a financial crisis which prompted the Dutch government to provide exceptional financing at the end of 1999 , after a new coalition government took office (SA Tables 12 and 13). ${ }^{5}$

\section{In 2000, the positive impact on the budget of new tax and wage cost measures} was offset by a collapse of tax collection during the final months of the year. At end1999, turnover tax rates on the Leeward Islands were raised from 2 percent to 5 percent, boosting central government revenues in 2000 . Tumover tax rates for the Windward Islands were adjusted from 2 percent to 3 percent in April 2000. The resulting revenue increase permitted the resumption of regular transfer payments from the central government to the island governments. ${ }^{6}$ However, profit tax collection started to taper off by mid-2000, and declined dramatically during the last quarter, due to lower offshore dividend inflows. In addition, indirect tax collection collapsed, as a result of a disruptive reorganization of the tax administration. In spite of considerable efforts to clear backlogs and a successful technical assistance project for the tax auditing service, the overall shortfall in tax revenue amounted to $13 / 4$ percent of GDP (NA f. 75 million). Financing constraints and the postponement of budgeted expenditures of about 1 percent of GDP limited the deficit to $31 / 4$ percent of GDP (NA f. 144 million). Most of the financing was obtained from external sources. Dutch support during September-December amounted to 13/4 percent of GDP and Aruba settled an outstanding debt of $3 / 4$ percent of GDP.

\section{The expenditure carryover from 2000, tax collection problems, and new} spending plans have undermined the fiscal consolidation planned for 2001 . The budgetary outlook is also adversely affected by the weak economy and delays in pension and health care reform. The 2001 budget targeted a reduction in the overall deficit to less than 2 percent of GDP. But, without further adjustment, it is now slated to rise to about 5 percent of GDP. The authorities intend to implement further adjustment policies to contain the deficit to last year's level, which would represent a significant improvement in the primary balance.

\footnotetext{
${ }^{5}$ Dutch financing shows up as monetary financing in SA Table 12, reflecting on-lending to the government of Dutch funds deposited at the central bank.

${ }^{6}$ On the other hand, a government guarantee for the Parker hotel project entailed outlays amounting to $3 / 4$ of one percentage point of GDP.
} 
Nonetheless, domestic financing prospects remain bleak and large external support will be required to meet the budget's financing needs.

\section{Money, Banking, and Financial Sector}

\section{Buoyant money and credit developments during 1999-2000 were at odds with} the weakening of the economy. Both money and credit increased faster than nominal GDP (SA Table 14). Stronger money demand stemmed from investors, who-having lost their confidence in government paper-looked at bank deposits as a safer investment. The apparent divergence of trends in credit and economic activity is partly explained by changes in the provision of bank credit for new investment projects (particularly in the Windward Islands) through foreign-owned banks, which borrowed funds from their home branches. However, another part of the strong credit growth reflects commercial bank's willingness to refinance maturing loans including interest ("evergreening"). Even though much of this credit is collateralized (SA Table 15), there is ample evidence of a deterioration in the underlying quality of collateral, especially real estate. Moreover, the authorities tolerated noncompliance with the monetary reserve requirement in an attempt to avoid an undue credit crunch.

\section{The relatively large increases in domestic assets at a time of recession took a toll} on the banking system's foreign assets. Indeed, in addition to setting higher reserve requirements, which were, however, not consistently enforced across banks, ${ }^{7}$ the central bank allowed net international reserves to fall to sterilize some of the credit expansion. Such a policy resulted in very stable interest rates (SA Table 16), but at the cost of reaching a near historically low reserve cover, especially if Dutch financial assistance placed on deposit at the central bank is excluded. ${ }^{8}$

17. The quality of banks' balance sheets has continued to deteriorate (SA Table 17). The soundness of the banking system has suffered from rising nonperforming loans, and the attendant need for higher provisioning which has sharply lowered profitability. Given these developments, the central bank has stepped up its supervisory capacity and efforts, inter alia through targeting more fiequent on-site inspections to banks suspected of being in relatively more difficult situations.

\section{Nonbank financial Institutions have adopted a "wait-and-see" approach to} domestic investment (SA Table 18). The large insurance companies in particular are reducing their exposure to government paper by increasingly refusing to roll over maturing securities. Moreover, insurance companies and pension funds, having been important players

\footnotetext{
${ }^{7}$ The penalty rate on a shortfall in required reserve holdings was considerably lower than prime lending rates.
}

Such assistance is usually geared toward financing the budget deficit or specific investment projects, and thus is not available for monetary policy purposes. 
in the mortgage market in the past, have become less willing to extend new mortgage finance in view of falling real estate valuations. Also, given the historically high incidence of hurricanes in the recent past, and the attendant losses of insurance companies, there has been both a widespread exit of insurance companies from hurricane insurance policies and significant premium increases for policy holders. In other areas (e.g., car insurance), insurance companies have asked for a deregulation of prices for insurance premia in order to be able to strengthen incentives against moral hazard.

19. The prospects for the offshore sector have become increasingly uncertain over the past two years. While assets under management have continued to increase, they are still below past peaks (SA Table 19). Participants in the sector indicated that they were looking ahead with more optimism after the clarification of the tax regime vis-à-vis the Netherlancs and the U.S. (see Chapter 3 for a more detailed discussion of the offshore sector).

\section{Balance of Payments}

\section{The overall balance of payments has recorded a deficit for the second year} running. This reflected an increase in the current account deficit by some 4 percentage points of GDP in 1999-2000. Even with exceptional foreign financing, the capital and financial account - adversely affected by poor economic prospects - failed to provide a sufficient surplus (SA Table 20).

\section{In 1999-2000, most components of the current account registered a significant}

deterioration. Sharp declines in the merchandise trade, services, and income balances resulted in a current account deficit of some 8 percent of GDP, notwithstanding the recent small improvement in the transfer balance owing to exceptional support (SA Tables 21 and 22). A large pickup in demand for imports resulting from higher oil prices, the need to restock and rebuild after the hurricanes in the Windward Islands, and the start up of new investment projects resulted in an 8.5 percent nominal increase in merchandise imports in 2000. Export growth-in part reflecting higher oil prices, which also lifted bunker revenues - was insufficient to avoid a decline in the trade balance. Moreover, the free zone, facing stiffer regional competition, witnessed a fall in exports. The services balance was adversely affected by a large increase in tourism expenditures, ${ }^{9}$ and a decline in refinery receipts as the refinery went through a restructuring program. On the other hand, the offshore sector recorded a small increase in its net operating balance and tourism receipts staged a strong recovery from their hurricane-related troughs in the previous years.

\footnotetext{
${ }^{9}$ The recorded increase in tourism expenditure is, however, likely to be largely a statistical artifact, resulting from the cash recording of the balance of payments through commercial banks which tend to assign any individual foreign currency withdrawals and purchases to tourism expenditures.
} 
22. The capital account surplus has been insufficient to cover the current account deficit. The capital account balance registered a large drop in 2000 , reflecting the non receipt of previous development aid as the emergency financing of the government budgetrecorded in the transfer balance - was accorded primacy by donors (SA Tables 23-26). Moreover, poor economic prospects reduced direct investment activity. On the other hand, external financing of some private-sector investment projects led to a significant pick up in other investment inflows. Finally, it is worthy to note that portfolio and other investment flows have recorded large gross increases (i.e., on both inflows and outflows) over the last two years. A large part of the recorded increase arguably owes to better recording of offshore-sector related transactions as a result of recent efforts to strengthen the regulation of the sector (see Chapter III).

\section{Net international reserves have registered a large decline in 1999-2000}

(SA Table 27). While the central bank was able to limit the loss in its official reserves so as to achieve a merchandise import cover of some two months, commercial banks' net international reserves fell sharply. The latter trend partly reflects the increasing presence of foreign-owned banks, which are able to incur foreign liabilities with their head offices, as well as the fact - discussed above - that credit conditions have been kept loose against the background of a weak economy. However, since banks are for prudential reasons not permitted to have a negative net foreign asset position, and official reserves cover of imports has reached a very low level, this trend is no longer sustainable. 


\section{Adjustment Policy in the Presence of Labor Mobility , 1999-2001 ${ }^{1}$}

\section{A. Introduction}

24. In response to a deteriorating economic situation since the mid 1990s, the Antillean authorities have introduced several adjustment initiatives. However, so far, the economy has not recovered, as evidenced by continued high unemployment, outward migration, and depressed fiscal revenues and liquidity problems at both levels of government (Box 1). Preparations of a Fund-staff supported adjustment program began in 1996, but the initiative went off track shortly after the mid-1997 start of the program. A subsequent attempt in 1998 to jump start the economy, including through tax relief, was short-lived because of escalating liquidity problems. Since end-1999, a renewed adjustment effort has been underway, comprising both fiscal and structural measures.

Box 1. Coverage of the General Government

The general government comprises the central government and the island government of Curaçao, which has a considerable degree of fiscal autonomy, but only limited control over the revenue side of its budget, as tax policy is mostly determined by the central government. The island government collects all direct taxes, whereas (until April 2001) most indirect taxes were collected by the central government. A portion of tax revenue is redistributed through revenue sharing arrangements. The smaller islands do not take part in these arrangements. They do, however, receive contributions of the so-called "Solidarity Fund" which is jointly financed by the central government ( 55 percent), Aruba (25 percent) and the Netherlands (20 percent).

Social funds responsible for social security and health care schemes and the public sector pension fund (APNA) are not included in the general government A large part of public investment is financed outside of the budget.

25. This chapter describes the most recent adjustment effort, focusing on the following issues:

- the underlying sources of the ongoing economic crisis;

- the adjustment measures that have been implemented so far;

- the remaining key challenges for restoring growth prospects.

\footnotetext{
${ }^{1}$ Prepared by Jan Kees Martijn.
} 


\section{B. Causes of the Economic Crisis and Way Out}

26. Labor mobility within the Kingdom of the Netherlands constrains adjustment of the Antillean economy to external shocks. Given largely free movement of labor, workers tend to move to the location that provides the highest productivity-reflected in wages and job availability. Accordingly, the Antilles has specialized in those products (mainly tourism, port-related activities, and international financial services) for which it offers a clear locational advantage, plus the nontraded products (for example, retail and utilities) associated with these activities. For virtually all other production taking place within the Kingdom, the Netherlands seems to provide a preferred location. Presumably, this reflects the limited scope for exploiting internal and external scale economies on the Antilles (with a total population of 200,000 distributed over five islands) and the locational advantages of the Netherlands as a mainport to other parts of western Europe. It follows from this stylized description that (positive or negative) shocks in the Antilles tend to lead to migration rather than to domestic labor reallocation. ${ }^{2}$ Moreover, the eventual change in employment following a shift in the locational advantages for the tradables sector of the Antillean economy will exceed the initial shock, since employment in the nontraded goods sector will also be affected.

\section{During the past decade and a half, adverse shocks have affected each of the major sectors of the economy of the Netherlands Antilles.}

- Less favorable foreign tax arrangements since 1984 and, in recent years, heightened international scrutiny of offshore centers have caused a decline in demand for their services and, more importantly, greatly reduced tax revenues from this sector (see Chapter III).

- A second shock has been the negative impact of successive hurricanes since 1995 on tourism infrastructure and demand, especially on St. Maarten. The hurricanes ended a boom in the tourist sector during the first half of the 1990s.

- The transfer of refinery activities from Shell to the Venezuelan state oil company in the mid-1980s reinforced the trend decline in employment and also reduced the tax earnings of the island govermment of Curaçao. Increased labor productivity in this

\footnotetext{
${ }^{2}$ Because of indivisibilities in the adjustment process, the attainment of a new equilibrium through such migration may not be a smooth process. For example, in case of outward migration, the departure of providers of nontraded services and the higher average fixed costs of utilities may first provoke further emigration until the process is dominated by the positive effect on labor productivity (in value terms) of having more fixed production factors available per worker and/or a higher product price.
} 
largely fixed-capacity facility is necessary for maintaining competitiveness but implies a declining workforce. ${ }^{3}$

While this contractionary process would be expected to bottom out eventually, it can imply a significant downsizing of the Antillean economy. Between 1992 and 2000 , the population of Curaçao already fell by about 10 percent.

28. The impact of adverse shocks has been aggravated and prolonged by economic rigidities and the absence of an adequate policy response. Domestic adjustment, through a reallocation of resources, is hampered by labor market rigidities and an excessive regulatory burden. A further problem has been a lack of fiscal accommodation. The decline of the tax base has not been matched by adequate expenditure restraint. As a result, domestic taxes (i.e., excluding offshore profit taxes) had to be raised by $4 \frac{1}{2}$ percent of GDP between 1990 and 1999 - further depressing activity and adding to the labor outflow. In addition, the general government deficit expanded, reducing financial resources for private domestic investment. Finally, the government's liquidity problems have spilled over into the private sector through the accumulation of arrears to private suppliers, and have eroded economic confidence in general,

29. The incentive to persevere with politically difficult adjustments has been undermined by the expectation of external financing. In principle, structural adjustment validates additional financing from abroad, in order to allow the temporary adjustment costs to be spread over a longer period (a consumption-smoothing argument). Concessional financing can also promote adjustment by reducing the associated short-term political costs. However, in the Antilles, repeatedly adjustment was implemented only partially or was subsequently undone, while foreign financing was provided after all--creating, and, in turn, validating bailout expectations.

\section{Stemming the decline in labor demand hinges on sustained policies to lower} production costs, in particular in tourism, for which demand is relatively elastic. Economic efficiency can be promoted by reducing the excessive red tape, which in part results from a duplication of activities and a lack of coordination between the two layers of government. Also, the high costs of utilities could be reduced, ${ }_{2}$.g., through liberalization and strict oversight. For a tourism-oriented economy, enhancing labor market flexibility is essential, allowing firms to tailor the provision of services to peak demand without excessive costs. To some extent a recovery of private investment can by itself enhance productivity through sector-wide economies of scale. For example, it is argued that solving the existing bottleneck of too limited airlift capacity for tourists to Curaçao depends on reaching a threshold regarding the number of hotel rooms on the island. Finally, it is important to phase

\footnotetext{
${ }^{3}$ Refinery employment has shrunk from a peak of about 20,000 in the 1950 s to less than 1,500 in recent years.
} 
out the extensive protection against import competition early on within the adjustment process, in order to avoid wasteful investment in fundamentally uncompetitive sectors.

31. A recovery of private investment also requires continued efforts to address fiscal imbalances. Fiscal consolidation is essential for restoring confidence, breaking the chain of payments arreats, avoiding excessive domestic nonbank financing, and, if possible, making room for tax cuts while ensuring adequate public infrastructure. In addition, simplification of the tax system would help, as the complexities of the current system pose an unnecessary burden on enterprises and workers.

\section{1999-2001 Adjustment Initiative}

\section{The authorities' current adjustment initiative provides a much needed} opportunity for restoring growth prospects for the NetherIands Antilles. In 1999, estimated real GDP was no higher than in 1994, and unsustainable fiscal deficits had led to an increase in the public sector debt stock to more than 70 percent of GDP, from about 40 percent in 1990 . Efforts to bring about a turnaround have been aided by the central government's new authority, since July 2000 , to rule by decree on a range of topics. In September 2000 , a comprehensive policy program was adopted, designed with Fund staff assistance for the period up to March 2001. Financial assistance was provided by the Netherlands-first, at end-1999, to avoid a looming liquidity crisis and largely based on the promise of reform, and later, between September and November 2000, based on compliance with agreed program targets.

\section{Fiscal policy}

\section{Addressing the fiscal imbalances was a priority within the adjustment strategy.} By mid-1999, shortfalls in tax collection and mounting refinancing problems were reflected in growing liquidity shortages. In the first six months of the year, tax revenue (in nominal terms) was 4 percent lower than during the same period in 1998, mainly as a result of a 1998 wage and income tax relief package and an ill-prepared replacement in early 1999 of the sales tax on the Leeward Islands by a turnover tax. Expenditures still edged up, implying an increase in the half-year deficit from NA f. 60 million in 1998 to NA f. 100 million ( $21 / 4$ percent of annual GDP), about half of which was financed through pension premium arrears. As an indication of the adjustment need, without additional measures, the deficit would have risen from NA f. 104 million in 1998 to about NA f. 270 million (6\%/4 percent of GDP) in 1999. At the time, available regular donestic financing was estimated to be about 1 percent of GDP.

\section{The escalating financial problems reflected several structural weaknesses regarding the tax system, tax collection, and expenditure control.}

- A tax base narrowed by a multitude of exemptions to both direct and indirect taxes;

- Administrative problems hampering tax collection, reflected in excessive collection arrears; 
- Overly optimistic projections of economic growth and tax revenue;

- A proliferation of often disputed claims among public entities and disregard for existing rules on budgeting and reporting, undermining fiscal discipline;

- A surge in interests costs during the 1990 s as a result of increased deficit financing;

- Unsustainable cuts in spending on goods and services and investment forced by liquidity shortages, rather than as a result of a deliberate strategy;

- Erosion of attempts to limit the wage bill, through new hirings, increased use of overtime, and a costly job regrading exercise.

\section{The recent adjustment initiative has addressed most of these budgetary}

weaknesses, although so far with varying degrees of success (see Table1). Restoring tax revenue was an indispensable first step. The turnover tax rate on the Leeward Islands was raised from 2 percent to 5 percent starting in October 1999. With an expected revenue effect of more than NA f. 100 million, this was by far the largest measure within the program. Limits on exemptions to wage and income taxes were introduced by decree in July 2000. On the expenditure side, extensive reforms were implemented with the aim of lowering wage costs, including the dismissal of about 20 percent of civil service staff and a wage freeze. The size of the sinking fund needed to anticipate rising pay-as-you-go pension obligations has been reduced by the phasing out of the early retirement system by 2008 and the inclusion (although with some exceptions) of the basic old-age pension into the pension base for civil servants starting in 2002.

36. Nonetheless, the immediate benefits from the efforts to improve the health of the public finances have so far been limited. For example, the cost savings resulting from the public sector layoffs are constrained by the generosity of the severance payment regime. ${ }^{4}$ Also, restoring budgetary integrity implies meeting obligations (in particular regarding pension and health insurance premiums) that in the past were often neglected. The regularization of arrears and claims through new loans is reflected in sharply higher interest costs. Finally, restructuring has entailed large adjustment costs. In particular, poor execution of the decentralization of the tax administration led to a collapse of collection efforts at the end of 2000. As a result, after a mid-year revision that brought the 2000 budget in line with the adjustment initiative, execution of the revised budget went off track almost immediately, and sizable expenditures had to be postponed to 2001 .

\footnotetext{
${ }^{4}$ Civil servants dismissed prior to January 1,2000 , can receive up to four years severance pay, depending on years of service, with the replacement rate declining in four steps from 100 to 70 percent. For dismissals after January 1, 2000, the duration of severance pay has been limited to two years.
} 
Table 1. Netherlands Antilles: Main Fiscal Measures Adopted Under the 1999-2001 Adjustment Initiative

\begin{tabular}{|c|c|c|}
\hline Measure & Implementation & Remarks \\
\hline $\begin{array}{l}\text { Turnover tax on Leeward Islands increased } \\
\text { from } 2 \text { percent to } 5 \text { percent. }\end{array}$ & October 1999 & \\
\hline $\begin{array}{l}\text { Sales tax on Windward Islands increased from } \\
2 \text { percent to } 3 \text { percent. }\end{array}$ & May 2000 & $\begin{array}{l}\text { Proceeds transferred to the } \\
\text { Windward Islands. }\end{array}$ \\
\hline Wage and income tax base widened. & July 2000 & $\begin{array}{l}\text { Restoration to levels before } \\
1998 \text { tax relief. }\end{array}$ \\
\hline $\begin{array}{l}\text { Tax auditing strengthened with assistance by } \\
\text { Dutch experts. }\end{array}$ & June-Dec. 2000 & \\
\hline Tax collection backlogs cleared. & 2000 and 2001 & \\
\hline $\begin{array}{l}\text { Central Government (CG) and Island } \\
\text { Government of Curaçao (IGC) tax collectors } \\
\text { merged and automated tax collection system } \\
\text { (GOS) implemented. }\end{array}$ & April 2001 & \\
\hline Tax inspectorates decentralized. & April 2001 & $\begin{array}{l}\text { Inspectorates are to merge } \\
\text { with tax collectors. }\end{array}$ \\
\hline $\begin{array}{l}\text { Civil servants' wage indexation and periodic } \\
\text { salary adjustment suspended (until } 2002 \text { ). } \\
\text { Vacation allowances reduced by half. }\end{array}$ & January 1,2000 & $\begin{array}{l}\text { Wage freeze and salary } \\
\text { adjustment stop expire in } \\
2001 \text {. }\end{array}$ \\
\hline Vacation allowances suspended. & August 2000 & $\begin{array}{l}\text { Partly compensated by extra } \\
\text { leave. }\end{array}$ \\
\hline 1,127 IGC employees dismissed. & July 1999-Jan. 2001 & Out of a total of 3,870 staff. \\
\hline 744 CG employees dismissed. & $\begin{array}{l}693 \text { effective end- } \\
\text { Feb. } 2001\end{array}$ & $\begin{array}{l}\text { Out of a total of } 3,800 \text { staff; } \\
\text { including } 63 \text { projected new } \\
\text { hirings. }\end{array}$ \\
\hline CG hiring frozen. & $\begin{array}{l}\text { Since } \\
\text { September } 2000\end{array}$ & $\begin{array}{l}\text { To be replaced by ceilings } \\
\text { on positions per department. }\end{array}$ \\
\hline $\begin{array}{l}\text { Pension contributions reduced by } 2 \text { percentage } \\
\text { points. }\end{array}$ & January 2000 & \\
\hline Early retirement option phased out by 2008 . & & $\begin{array}{l}\text { Limiting need for creating a } \\
\text { sinking fund. }\end{array}$ \\
\hline $\begin{array}{l}\text { Basic old-age pension included into pension } \\
\text { base (with exceptions). }\end{array}$ & Starting in 2002 & Limiting pension costs. \\
\hline $\begin{array}{l}\text { Expenditure on goods and services and } \\
\text { investment curtailed. }\end{array}$ & 1999 and 2000 & $\begin{array}{l}\text { In part forced by liquidity } \\
\text { constraints. }\end{array}$ \\
\hline $\begin{array}{l}\text { Matrix of intragovernmental debts, arrears, and } \\
\text { claims developed. }\end{array}$ & December 2000 & $\begin{array}{l}\text { Preparing financial } \\
\text { settlement among } \\
\text { government entities. }\end{array}$ \\
\hline $\begin{array}{l}\text { Smaller islands' draft } 2001 \text { budgets submitted } \\
\text { to CG for approval. }\end{array}$ & December 2000 & \\
\hline
\end{tabular}

Source: Data provided by the Antillean authorities. 
37. Upgraded procedures to improve budgetary discipline are being put in place. For example, the island government of Curaçao is implementing procedures to control the costs of autonomous agencies that have become more important as a result of the recent divestiture of government services. Also, a settlement of accumulated arrears to the pension fund has been arranged--albeit not yet formalized. To prepare for a comprehensive settlement of intragovernmental debts, arrears, and claims, a matrix has been created listing all reported obligations.

\section{Structural measures}

38. Structural measures to boost an economic recovery have focused on strengthening market forces and streamlining public sector operations (Table 2). The goal of these policies is to bolster productivity and reduce business costs—crucial for attracting investment.

39. Protection of domestic manufacturers is being dismantled. A decree eliminating production monopolies was introduced in November 2000. The phasing out of the import protection regime by 2005 was started in early 2001 with the abolition of several import prohibitions and the first round of reductions of the so-called "economic tariffs".

40. For an economy that is highly dependent on tourism, labor market flexibility is key. However, new labor legislation adopted at end-1998 stipulated a reduction and more rigid application of the maximum workweek and the extension to the private sector of the generous maternity leave provisions already applying to public sector workers. To ensure sufficient flexibility, further changes were adopted in the second half of 2000 , regarding the dismissal regime and working hours. ${ }^{5}$

41. Public sector reform is another element of the authorities' structural reform program. Since 1997, both levels of government have streamlined their operations. In addition to the layoffs, noncore tasks have been divested to autonomous foundations and private enterprises. In order to limit duplication of activities between levels of government, a decentralization process has started, with the decentralization of tax assessments and tax collection completed by April 2001. Regarding privatization, both the central government and the island government of Curaçao had adopted a formal framework by end-2000, including a list of companies to be privatized.

\footnotetext{
${ }^{5}$ The new initiative also included a potentially costly equalization of minimum wages across the various islands and job categories, but implementation of this measure has been deferred.
} 
Table 2. Netherlands Antilles: Main Structural Measures Adopted Under the 1999-2001 Adjustment Initiative

\begin{tabular}{|c|c|c|}
\hline Measure & Implementation & Remarks \\
\hline \multicolumn{3}{|l|}{ Business environment } \\
\hline $\begin{array}{l}\text { Six import bans abolished and the first round of } \\
\text { reductions (by } 15 \text { percent) of the economic tariffs } \\
\text { implemented. }\end{array}$ & March 2001 & $\begin{array}{l}\text { Market protection regime to be } \\
\text { phased out by } 2005 \text {. }\end{array}$ \\
\hline Production monopolies eliminated. & November 2000 & $\begin{array}{l}\text { Until } 2005 \text {, the companies remain } \\
\text { protected by the economic tariffs. }\end{array}$ \\
\hline $\begin{array}{l}\text { Pilot project (for notaries) initiated for electronic } \\
\text { application for business establishment permit. }\end{array}$ & October 2000 & \\
\hline Law facilitating e-commerce adopted. & Jamuary 2001 & \\
\hline A one-stop shop for foreign investors proposed. & March 2001 & \\
\hline \multicolumn{3}{|l|}{ Labor market } \\
\hline $\begin{array}{l}\text { Individual dismissal permit requirement abolished } \\
\text { for all productive sectors on Curaçao; tourism sector } \\
\text { exempted from new legislation on working time; } \\
\text { proposed increase in minimum wages deferred. }\end{array}$ & September 2000 & $\begin{array}{l}\text { New labor legislation had been } \\
\text { adopted in July } 2000 \text { regarding the } \\
\text { dismissal regime, working hours, } \\
\text { and minimum wages. }\end{array}$ \\
\hline $\begin{array}{l}\text { Admissible regular working hours per day raised } \\
\text { from } 9 \text { to } 10 \text {. }\end{array}$ & December 2000 & \\
\hline $\begin{array}{l}\text { Reduction in pay allowed if, as a result of } \\
\text { application of the new labor legislation, working } \\
\text { time is reduced. }\end{array}$ & March 2001 & \\
\hline $\begin{array}{l}\text { Restrictions on work permits for workers from the } \\
\text { Netherlands relaxed (but not abolished). }\end{array}$ & August 2000 & \multirow{2}{*}{$\begin{array}{l}\text { An overall revision of work and } \\
\text { residence permits has been } \\
\text { subrnitted to Parliament. }\end{array}$} \\
\hline $\begin{array}{l}\text { Residence permits for Dutch and Aruban citizens } \\
\text { liberalized. }\end{array}$ & March 2001 & \\
\hline \multicolumn{3}{|l|}{ Public sector reform } \\
\hline $\begin{array}{l}\text { Activities divested to autonomous institutions } \\
\text { including } 577 \mathrm{CG} \text { and } 169 \mathrm{IGC} \text { employees }\end{array}$ & $\begin{array}{l}\text { CG: mostly Nov. } \\
2001 \\
\text { IGC: Jan. 2001 }\end{array}$ & $\begin{array}{l}\text { Control procedures to ensure } \\
\text { transparency and efficiency are } \\
\text { under preparation. }\end{array}$ \\
\hline $207 \mathrm{CG}$ positions transferted to the islands. & April 2001 & \\
\hline $\begin{array}{l}\text { Framework for privatization adopted, including list } \\
\text { of companies to be privatized, and stipulations on } \\
\text { use of proceeds for debt reduction or investment in } \\
\text { infrastructure and human capital, only. }\end{array}$ & November 2000 & $\begin{array}{l}\text { At the IGC level, an autonomous } \\
\text { foundation has been established for } \\
\text { the execution of the privatizations. }\end{array}$ \\
\hline Privatization of APNA decided. & October 2000 & \\
\hline \multicolumn{3}{|l|}{ International financial services } \\
\hline $\begin{array}{l}\text { New Fiscal Regime (NFR) approved, effective } \\
\text { January } 2001 \text {. }\end{array}$ & December 1999 & $\begin{array}{l}\text { To end the status of the Antilles as } \\
\text { offshore tax jurisdiction by } \\
\text { adjusting fiscal laws and } \\
\text { regulations to international norms. }\end{array}$ \\
\hline $\begin{array}{l}\text { New Fiscal Regime agreed with Netherlands. The } \\
\text { combined withholding tax, of } 8.3 \text { percent, to be } \\
\text { transferred to the Antilles. }\end{array}$ & December 2000 & $\begin{array}{l}\text { New regime will become effective } \\
\text { in } 2002 \text {, with a transitional } \\
\text { arrangement for } 2001 \text {. }\end{array}$ \\
\hline $\begin{array}{l}\text { Commitment Letter issued to terminate 'harmful tax } \\
\text { practices' within five years and comply with OECD } \\
\text { requirements. }\end{array}$ & November 2000 & $\begin{array}{l}\text { Commitment sets in motion an } \\
\text { evaluation process of existing } \\
\text { legislation. }\end{array}$ \\
\hline
\end{tabular}

Source: Data provided by the Antillean authorities. 


\section{Outstanding Initiatives and Remaining Challenges}

\section{Short-term budgetary prospects depend strongly on a return of regular tax} collection and expenditure control. As of April 2001, with the formal integration of the tax receivers and the tax inspection, now all at the island level, collection should no longer be hampered by organizational problems and uncertainty. However, given a large carry over of expenditures from 2000 and severe refinancing problems, rapid action to limit planned spending, for example on health care, and access to additional foreign financing will be needed to ensure the viability of the 2001 budget. In this context, a major challenge will be the containment of budgetary risks, including possible claims resulting from the past extension of guarantees to hotel projects and losses incurred by public enterprises, in particular the national airline.

43. The medium-term sustainability of the public finances will depend on the success of several interrelated initiatives to strengthen budgetary discipline. A comprehensive settlement of all debts, arrears and claims within the public sector is awaiting completion of an inventory of the amounts involved. A first part of such settlement, covering the pension premium arrears of the various government bodies, has been delayed as the island of Bonaire saw no scope for meeting the resulting financing obligations within the existing revenue allocation. This allocation, in turn, is to be adjusted in the context of the current revision of the Solidarity Fund - a redistribution system within the Kingdom of the Netherlands, supporting the smaller islands. As a further complication, the distribution of the financial room among all Antillean government entities is in a state of flux as a result of the recent decentralization of tax collection. Finally, the ultimate objective of the comprehensive debt settlement - restoring payment discipline-also depends on the timely adoption of consistent budgets for all entities and on new procedures to monitor budget execution

44. A comprehensive review of administrative procedures and the tax system, with the objectives of reducing the administrative burden and promoting the functioning of labor and product markets, has yet to be undertaken. The authorities plan to eliminate the cascading element of the turnover tax system, which currently distorts market structures. Much remains to be done in order to reduce the costs and delays that result from, for example, onerous licensing procedures, difficulties in obtaining work and residence permits for foreign workers, overtime restrictions, and overly complex tax arrangements. The authorities have obtained assistance from the World bank and FIAS to help them in this exercise. Liberalization and privatization are planned to be accompanied by the introduction of a regulatory board for utilities and a competition law in order to avoid abuse of market power. 


\section{DEVelopments IN OfFShore FINANCIAL SERVICES ${ }^{1}$}

45. The offshore sector has been a fixture of the Antillean economy for more than 30 years and can trace back its origins even further to the movement and registry of Dutch assets to the islands in the run-up to the occupation of the Netherlands in World War II. The initial growth of the sector in the late 1960 s was boosted by the distortionary capital controls then prevalent in industrial countries. With the advent of capital liberalization in industrial countries, the focus of the offshore sector has become more oriented toward providing a lowtax environment for corporations and individuals, as well as intermediating capital flows from Latin America, where the speed of capital liberalization has been slower. The success in providing a venue for significant tax savings, however, triggered closer scrutiny and efforts on the part of industrial countries to stem tax and regulatory evasion, which arguably have dampened the growth of the sector in recent years. In any event, the importance of the sector for the Antillean economy has declined significantly over the past decade and a half.

46. At present, the offshore sector directly contributes some eight percent of GDP to the Antillean economy; employs, including dependent employment, more than five percent of the labor force; and has total assets of some US $\$ 28$ billion under management. The future will hold challenges for offshore centers in general, but there are signs that the Antillean offshore sector has already begun to position itself to benefit from a more integrated global economy. This chapter discusses in turn some general aspects of offshore centers, the recent international policy initiatives regarding offshore sectors, the main features of the Antillean offshore sector, and the response of the Netherlands Antilles to international initiatives. Following an empirical exploration of the determinants of offshore activities, the chapter concludes with some remarks on the prospects for the Antillean offshore sector.

\section{A. Some Basics on Ofrshore Operations}

47. There is no single comprehensive definition of "offshore" activities. The term offshore center describes jurisdictions that encourage the establishment of companies $b y$ nonresidents for the purpose of engaging in business with nonresidents. Such offshore activities are mostly associated with financial transactions, but can also occur for other goods and services, for example in export processing zones or in shipping. In this chapter, however, the term offshore center is limited to jurisdictions providing offshore financial services.

Furthermore, while the designation "offshore" is often associated with small tax havens, it is important to note that the vast majority of offshore financial operations (again transactions of nonresidents with nonresidents and/or in nonresident currencies) takes place in major international financial centers such as "Euromarkets" in London and New York (see Hampton, 1996). In an attempt to delineate offshore financial centers (OFCs), the relevant literature distinguishes three types (see Cassard, 1996 and SM/00/136, Supplement 1). First, there are "international financial centers" such as London, New York and Tokyo, which also

\footnotetext{
${ }^{1}$ Prepared by Gerwin Bell.
} 
have large and liquid domestic markets. Second, there are regional financial centers like Hong Kong, Singapore and Luxembourg, whose services are targeted to a particular geographic region. Finally, there are OFCs in much smaller jurisdictions that have cultivated certain niche markets. The range of services provided by this latter group is, however, quite large, spanning from activities that are complex and highly specialized to ones that can almost entirely be viewed in terms of tax and tegulatory arbitrage. This paper concentrates on the third group, in which the Netherlands Antilles falls.

\section{The attraction of offshore centers is largely related to "onshore" regulation,} taxation, capital controls, and political stability. There are four principal reasons for offshore centers. In the first instance, they can be used by individuals or companies to avail themselves of a more favorable tax regime than in their home countries, without having to move their operations away from their home countries. In a similar vein, they can be used to lower regulatory requirements. Offshore centers have also been instrumental in the circumvention of capital controls. Finally, they offer a way to protect assets from domestic seizure.

49. Offshore activities tend to be found in small island economies. There is a good reason for the geographic location of many OFCs in small islands, as they arguably enjoy a comparative - if not absolute - advantage. The offshore sector is generally not materially affected by these economies' resource constraints, as it is largely driven by imported human capital and communications technology. Moreover, the demands of an offshore sector fit well in the set of industries that an island economy could support. ${ }^{2}$ To the extent that such islands also cater to tourists, infrastructure and travel connections to onshore countries are in place, and in many cases a colonial background ensures a multilingual culture well catered to dealing with other countries' residents.

\section{B. Recent Challenges for Offshore Centers}

50. The future of offshore sector activity has recently become more uncertain, owing to increased integration of global markets and heightened scrutiny of offshore centers by the international community. Success of offshore centers in circumventing capital, tax, and regulatory controls has provided an additional impetus for moves toward large-scale capital liberalization and deregulation across the globe, such that now some of the pastures for offshore activity have dried up. In addition, renewed interest has recently centered on the potential for abuse of offshore centers for the purpose of tax evasion, money laundering, and undermining proper financial supervision. A number of international policy initiatives to address these issues bas been launched:

\footnotetext{
${ }^{2}$ This rationale is probably also responsible for the deliberate policy by ex-colonial powers to leave loopholes in legislation favoring the establishment of these OFCs as an alternative for development assistance.
} 


\section{Harmful tax practices}

51. In May 1996, the OECD was asked to analyze harmful tax practices, in particular through tax vehicles provided by offshore jurisdictions. The OECD (1998) has subsequently defined four key factors in identifying harmful tax practices:

- no or low effective tax rates: these are necessary for such practices to commence in the first place. The harmfulness of such practices, however, depends on the subsequent indicators.

- "ring fencing" of regimes: the extent to which specific (low) tax provisions are insulated from the domestic tax regime (for example by granting differential tax provisions for nonresidents only).

- lack of transparency: the extent to which the home country of a tax payer is able to objectively assess the tax provisions in the host jurisdiction.

- lack of effective exchange of information: insufficient exchange of information on taxpayers, which makes it difficult to detect tax evasion in the home country.

52. In an effort to reap the full benefits of globalization, the OECD countries have collectively committed to implement a standstill and rollback of harmful tax practices (i.e., not to introduce any new such measures and to phase out any existing ones by 2005). ${ }^{3}$ In addition, a dialogue has been initiated with other countries and jurisdictions with the aim of broadening the initiative and avoiding the displacement of harmful tax regimes to nonOECD jurisdictions.

\section{Money laundering}

53. A key feature in the development of offshore financial centers has been the high degree of protection accorded to the confidentiality privilege between financial services provider and client. While-as in the case of tax minimization - there are many legitimate uses of the confidentiality provisions, it is difficult to deny that they also provide an opportunity to conceal financial resources that arise from illicit activities. ${ }^{4}$ In this respect,

\footnotetext{
${ }^{3}$ Among its members, the OECD has identified potentially harmful tax regimes in Australia, Belgium, Canada, Greece, Hungary, Finland, France, Germany, Iceland, Ireland, Italy, Korea, Luxembourg, Netherlands, Norway, Portugal, Spain, Sweden, Switzerland, Turkey, and the United States (see OECD, 2000).

${ }^{4}$ Blum (1998) in a seminal report on recent money laundering techniques puts offshore centers at the center of money laundering through their provision of an enabling environment, notably bank secrecy.
} 
additional concern has been raised about Caribbean countries because of their geographical proximity to major drug trafficking routes.

54. In response to heightened concerns about money laundering, the G7 set up the Financial Action Task Force (FATF) in 1989, which elaborated 40 recommendations to combat money laundering. These can be broadly grouped into law enforcement related recommendations, and recommendations that seek to ensure proper customer identification. Over the 1990s, the FATF conducted two evaluations of its 29 member jurisdictions and also assessments of non-members' willingness to cooperate with FATF initiatives.

\section{Systemic regulation}

\section{In 1999, the Financial Stability Forum (FSF) considered the implications of} offshore financial centers for global financial stability. Following the Asian crisis and the events relating to the collapse of the LTCM fund, the international community had become concerned about the potential for volatility and systemic instability arising from poor supervision and oversight of large financial institutions. The FSF noted that offshore financial activities were not inimical to global financial stability, provided they are well supervised and their supervisory authorities cooperate (see FSF, 2000). As a corollary, the FSF concluded that offshore centers that are unable or unwilling to adhere to internationally accepted standards for supervision, cooperation, and information sharing do create a potential systemic threat to global financial stability. It called on the IMF to take responsibility for developing, organizing, and carrying out the process for assessing offshore centers" compliance with priority standards. Based on a survey, it identified three groupings of offshore centers according to the quality of their respective legal systems, supervisory abilities, and willingness to cooperate.

\section{Antillean Offshore Sector}

\section{Brief history and features of the Antillean offshore sector}

56. The ascent of the Antillean international financial sector owed much to tight capital controls in the United States and Europe in the 1960s (see Francis, 2000). These controls gave rise to the Eurodollar (and subsequent other Eurocurrencies, Eurobond, and Euronote) markets. While these markets were geographically based in "onshore" centers like London, it soon became advantageous for banks to book international loans in other, smaller jurisdictions. ${ }^{5}$ In particular, the Netherlands Antilles provided opportunities for smaller and medium-sized U.S. banks to tap the Eurodollar market, thus circumventing United States domestic capital controls in the form of a withholding tax on interest payments abroad. Owing to its tax treaty with the United States, the Netherlands Antilles presented the only withholding-tax free connection of U.S. corporate borrowers to the Eurobond market (see

\footnotetext{
5 This is the origin of the term "booking center," a term often used to describe smaller OFCs.
} 
SM/90/15). ${ }^{6}$ At present, anecdotal evidence points to considerable intermediation of Latin American financial resources as the liberalization of capital controls and financial sector development in Latin America have generally progressed at a slower pace than in industrialized countries. This was further accentuated by attractive returns in the U.S. equity market in which the Antillean offshore sector was able to intermediate.

57. The effective circumvention of capital controls probably alerted investors to the general potential of the Netherlands Antilles for tax minimization. The ease with which capital controls - which often were implemented as taxation on certain capital flows-were effectively avoided, highlighted the Netherlands Antilles' ability to drastically lower other forms of company and individual taxation for new clients. Indeed-with progressive capital liberalization in the large industrial countries - the focus of the Antillean offshore sector shifted to outright tax minimization. By registering a company in the Antilles, or other tax havens, and chaneling dividend and other payments through its books, it was possible to take advantage of tax treaties the Netherlands Antilles had with other countries (typically the home countries of such companies registered in the Antilles). The tax liability could thus be limited to the tax applicable in the Antilles, thus avoiding double taxation.

\section{The Antillean offshore sector also provided a venue for protection of assets from} seizure. As already indicated, an early episode was the transfer of many Dutch companies" assets to the Antilles prior to the occupation of the Netherlands in the World War II. This motive was also somewhat relevant for European residents during the cold war and, at the present time, for high-wealth individuals trying to shield assets from their families or law suits. Moreover, periodic asset confiscations in Latin America (for example of foreignexchange deposits at domestic banks) also created demand for channeling funds into the Antillean offshore sector. As in the case of tax minimization, however, concerns arose that illegitimately acquired assets may also have been unduly protected. The same caveat applies to regulatory arbitrage.

\section{Playing to tax and regulatory niches introduced inherent uncertainty and} vulnerability to the offshore sector. Indeed, if a niche market becomes significant, other actors (onshore and offshore) may try to enter. Since its inception, the Antillean offshore sector has both exploited and suffered from regulatory changes in onshore countries. The clear advantage of the Antilles in providing opportunities for tax minimization eventually backfired. Notwithstanding the low Antillean tax rates, revenue from offshore taxes to the Antillean budget reached almost one fifth of GDP in the early 1980 s, by far the largest single

\footnotetext{
${ }^{6}$ Prior to July 1984 , the United States had in place a withholding tax on interest payments to nonresidents, which, however, did not apply to the Netherlands Antilles as they were signatory to a double taxation treaty. This practice was permitted by U.S. regulators so as to avoid putting smaller U.S. banks at a disadvantage to larger multinationals which found it easy to avoid the foreign borrowing limits by borrowing through foreign subsidiaries. With a location in a very close time zone to the U.S., and well established links to the Netherlands and Europe, the Antilles were well placed to serve this demand.
} 
revenue component. Tax minimization through the Antilles and other offshore centers had thus acquired sufficient importance to trigger the termination of the tax treaties with the United States and the United Kingdom in 1984 and 85, respectively. Moreover, the United States implemented a withholding tax on dividend payments to the Antilles. ${ }^{7}$ Similarly, in the mid-1990s, Dutch legislation changed, preventing the establishment of Dutch pension funds in the Antilles and tightening the eligibility criteria for tax deductibility of corporate interest payments to related Antillean companies.

\section{The Antillean offshore sector has matured beyond being a registry for shell} companies as the sector had to find other niches. At present it is best described as a hybrid between a booking center and a more developed regional financial center. With average rates of growth of assets under management of more than 9 percent a year in U.S. dollar terms over the last 15 years, the Antillean offshore sector in 2000 has some $\$ 28$ billion under management (about 1,200 percent of Antillean GDP). However, its absolute direct contribution to Antillean GDP has significantly declined from some 20 percent in the mid$1980 \mathrm{~s}$ (mostly in the form of taxes) to some 8 percent in 2000 (about half of it in taxes). The indirect contribution of the sector to the economy continues to be significant, with direct and dependent employment estimated at more than five percent of the labor force.

\section{However, in comparative terms, the Antilles have recently Iost ground to other} offshore centers as indicated in Table 3. Between 1985 and 2000 the Netherlands Antilles has recorded a 240 percent increase in managed offshore assets, compared to a 190 percent increase in all BIS-defined offshore centers. Over the last five years, however, the country has registered considerably slower growth than other Caribbean jurisdictions.

Table 3. Netherlands Antilles: Growth in BIS Reporting Bank Claims on Offshore Centers, 1986-2000

(Annual percentage change)

\begin{tabular}{lrrrr}
\hline & $1986-1990$ & $1991-1995$ & $1996-2000$ & $1986-2000$ \\
\hline & & & & \\
AIl offshore centers & 14.0 & 9.6 & -2.2 & 7.2 \\
Excluding Hong Kong and Singapore & 9.5 & 7.2 & 13.4 & 9.9 \\
Caribbean offshore centers & 10.1 & 7.1 & 13.8 & 10.2 \\
Netherlands Antilles & 13.5 & 8.9 & 6.4 & 9.6
\end{tabular}

Source: BIS.

${ }^{1}$ Offshore centers in the BIS definition comprise: Aruba, Bahamas, Bahrain, Barbados, Bermuda, Cayman Islands, Hong Kong, Lebanon, Liberia, Netherlands Antilles, Parama, Singapore, Vanuatu, and the British West Indies.

\footnotetext{
${ }^{7}$ Even though grandfathering arrangements were made for Eurobonds issued earlier (the last such bond matured in 1992), revenue began to erode almost immediately.
} 
62. The present structure of the Antillean offshore sector is as follows: there are

- $\quad$ some 20,000 companies set up as "foundations" or "partnerships," most of them residing in the Netherlands, United States, East Asia, Spain, Italy, and Latin America, ${ }^{8}$ and individual clients from some 80 countries. These companies are administered by some 190 Antillean corporate management companies, of which about 70 are specializing in financial services, half of which belong to an international group with head office in the Netherlands Antilles. The beneficial owners of such companies tend to be foreign corporations as well as high-wealth individuals. The services of these companies reportedly span tax planning, captive banking and insurance, special purpose vehicles, as well as asset management.

- 33 offshore banks, most of them originating from Venezuela and the Netherlands. These banks' activities appear to be concentrated on providing financial services to nonbank offshore companies.

- about 1,100 new offshore companies registered each year, with some 600 companies being liquidated each year. ${ }^{9}$

- mainly activities in holding companies specializing in company, investment and intellectual property holdings, as well as shipping, trading, financing, and mutual funds.

- differentiated supervision requirements, with banks subject to supervision and auditing, and no supervisory or licensing requirement for other companies (other than the need to register with the company registry), and no mandatory audit requirement.

\section{The Antillean response to recent international policy initiatives}

63. The stepped-up international scrutiny of offshore centers leaves two opposite choices for offshore jurisdictions. On the one hand, the threat of sanctions and reputational considerations could set in motion efforts to improve the regulatory, tax, and supervisory environment, or - to the extent that such efforts were already under way - to strengthen existing moves in this direction. On the other hand, it is undeniable that such a response by "quality" offshore centers will also trigger incentives for other offshore centers that are less concerned about their reputation to take on new clients and activities no longer being served by offshore centers engaged in "regulating up."

${ }^{8}$ The minimum number of persons and directors required to form a company is one, with at least one director having to be a resident of the Netherlands Antilles.

${ }^{9}$ In a break with this pattern, in the 10 months through October 2000 , there were more company liquidations than new establishments. 
64. The general response of the Antillean offshore sector has been to "regulate up" so as to be able to ensure the continued survival of the international financial sector. By and large, the approach has so far been effective in that the Netherlands Antilles were able to avoid being singled out in the major international exercises, except that of the FSF.

\section{Taxation}

65. In June 2000, the $O E C D$ identified the Netherlands Antilles, along with 34 other jurisdictions as a tax haven. ${ }^{10}$ End-2000, the Netherlands Antilles-along with Bermuda, the Cayman Islands, Cyprus, Malta, Mauritius, San Marino, the Isle of Man, and the Seychelles-joined the OECD countries' commitment to eliminate harmful tax practices by 2005 ("level 1 commitment"), thus ensuring their removal from the OECD list of uncooperative jurisdictions. ${ }^{11}$

66. In late 2000, the Netherlands Antilles and the Netherlands agreed on a New Fiscal Framework governing the taxation of dividend flows between the two countries. After a transitionary period in 2001, the Dutch tax authorities will be collecting a tax of 8.3 percent on dividend payments going to the Netherlands Antilles - the current tax regime calls on the Dutch authorities to collect 5 percent and on the Antillean authorities to collect 3.3 percentand to transfer the proceeds to the Antillean government. This will put the mutual dividend tax regime between the Netherlands and the Netherlands Antilles in compliance with the relevant European Union guidelines. There had been widespread hopes in the Antillean offshore sector that an agreement with the Dutch could be reached that would have completely eliminated the taxation of dividend outflows to the Netherlands Antilles. Participants in the offshore sector nevertheless cheered the new arrangement as, in their view, it would restore a degree of certainty to the sector-reportedly sizeable dividend payments had been on hold pending the final agreement--and would place them in a position to again start to look into reaching double taxation agreements with other countries, initially at least through the connection with the Netherlands.

67. In addition, the United States Internal Revenue Service approved relevant Antillean banking regulations in June 2000. This will permit financial intermediaries located in the

\footnotetext{
${ }^{10}$ Being a tax haven does not necessarily imply that a jurisdiction also engages in harmful tax practices.

${ }^{11}$ At present, the OECD would, therefore, list as tax haven jurisdictions Andorra, Anguilla, Antigua and Barbuda, Aruba, Bahamas, Bahrain, Barbados, Belize, British Virgin Islands, Cook Islands, Dominica, Gibraltar, Grenada, Guemsey/Sark/Alderney, Jersey, Liberia, Liechtenstein, Maldives, Marshall Islands, Monaco, Montserrat, Nauru, Niue, Panama, Samoa, St. Christopher \& Nevis, St. Vincent and Grenadines, Tonga, Turks \& Caicos, US Virgin Islands, and Vanuatu (see OECD 2000).
} 
Netherlands Antilles to apply for "Qualified Intermediary Status," exempting them from otherwise applicable withholding taxes.

\section{Anti-money laundering initiatives}

68. The Netherlands Antilles have introduced money laundering regulations modeled on the Dutch anti-money laundering law with the following elements:

- the mandatory reporting of unusual transactions, which are defined on the basis of both subjective and objective indicators. Such transactions are being reported to a financial intelligence unit which then identifies suspicious transactions and reports them to law enforcement agencies. On the one hand, this requirement is broader than the reporting of merely suspicious transactions adopted by other countries. On the other hand, there is evidence that the Antillean authorities lack sufficient capacity to handle the large volume of such reported transactions. Moreover, the indicators may be defined too broadly, and efforts are currently underway to sharpen their focus. ${ }^{12}$

- measures to ensure customer identification. While there is no banking secrecy law in the Antilles, the confidentiality provision for financial services is held in high regard. Financial services providers-offshore and onshore-are mandated to follow a strict "know your customer" (KYC) policy. ${ }^{13}$ However, in ascertaining the identity of foreign clients, a service provider has, as a rule, to rely on proper identification by the refering bank. In addition, non-financial service providers such as lawyers, notaries, foundations, and partnerships are not covered by KYC nules. Even so, offshore services providers have reported that the incidence of bearer shares is rapidly declining.

- a broad provision for the confiscation of assets following conviction for financial abuse.

- the ongoing review of the effectiveness of the system.

69. Moreover, the Netherlands Antilles joined the Caribbean Financial Action Task Force, which adopted 19 recommendations in addition to the FATF's 40 , and also signed the UN Drug Convention in August 2000.

\footnotetext{
${ }^{12}$ For example, in 1997, there were 2,485 unusual transaction reports filed, of which 98 were eventually identified as suspicious and forwarded to law enforcement.

${ }^{13}$ This requires financial service providers to record the necessary customer identification before entering into a relationship or conducting transactions.
} 
70. Reflecting these steps to combat money laundering, following the second evaluation of the Netherlands Antilles, the FATF does not include the country on its list of "uncooperative jurisdictions" (15 as of February 2001). ${ }^{14}$

\section{Systemic regulation}

71. In its May 2000 report, the FSF placed the Netherlands Antilles in category III status, i.e., among the jurisdictions with the lowest regulatory standards, competence, or willingness to cooperate. ${ }^{15}$ In response, the Antillean authorities have expressed their view that supervision of the offshore sector was in line with international practice and is continuing to be stepped up. They also embarked on a self assessment-assisted by the Fund - of financial sector supervision (both onshore and offshore), which is expected to be made public later in the year. Based on the findings of this assessment, the authorities aim to redress any identified shortfalls.

\section{Overall performance in international fora}

72. The Netherlands Antilles have had some success in measuring up to heightened international scrutiny of offshore sectors (Table 4). With multiple "citations" concentrated on smaller and more recently established OFCs, the Netherlands Antilles are scored badly only by the FSF. Among OFCs in a similar position, it scores better than the Cayman Islands, but worse than Bermuda. However, Table 4 also provides some indication that, at least in the recent past, there has been some positive - if not statistically significant-correlation bctween growth in Caribbean offshore centers" assets and the number of "citations" issued by the OECD, FATF, and FSF, suggesting that the constraints imposed by efforts to improve regulation may well come at a cost to their offshore financial centers. ${ }^{16}$

\footnotetext{
${ }^{14}$ Noncooperative jurisdictions comprise the Bahamas, Cayman Islands, Cook Islands, Dominica, Israel, Lebanon, Liechtenstein, Marshall Islands, Nauru, Niue, Panama, Philippines, Russia, St. Kitts and Nevis, and St. Vincent and the Grenadines (see Financial Action Task Force, 2001).

15 The lowest grouping comprises of Anguilla, Antigua and Barbuda, Aruba, Bahamas, Belize, British Virgin Islands, Cayman Islands, Cook Islands, Costa Rica, Cyprus, Lebanon, Liechtenstein, Marshall Islands, Mauritius, Nauru, Netherlands Antilles, Niue, Panama, St. Kitts and Nevis, St. Lucia, St. Vincent and the Grenadines, Samoa, Seychelles, Turks and Caicos, and Vanuatu.

${ }^{16}$ The positive correlation between percent growth in assets over the last five years and number of "citations" issued (by FATF, FSF, or OECD) holds for the aggregate of Caribbean offshore centers for which BIS data are available: Aruba, Bahamas, Barbados, Bermuda, British Virgin Islands, Cayman Islands, Dominica, Grenada, Netherlands Antilles, St. Vincent and Grenadines, and Turks and Caicos.
} 
Table 4. Netherlands Antilles: Selected Indicators of Offshore Centers

\begin{tabular}{|c|c|c|c|c|c|c|c|}
\hline & \multicolumn{3}{|c|}{ Named on "black list" by: } & \multicolumn{4}{|c|}{ BIS Ieporting banks claims $3 f^{\prime}$} \\
\hline & $\begin{array}{c}\text { OECD } \\
\text { uncooperative } \\
\text { potentially } \\
\text { harmful tax } \\
\text { regime } \\
\end{array}$ & $\begin{array}{c}\text { FATF } \\
\text { uncooperative } \\
j \text { turisdiction }\end{array}$ & $\begin{array}{c}\text { FSF } \\
\text { III rating 2/ }\end{array}$ & $\begin{array}{l}\text { in perce } \\
\text { domestic } \\
\text { GDP }\end{array}$ & $\begin{array}{l}\text { nt of } \\
\text { broad } \\
\text { money }\end{array}$ & $\begin{array}{l}\text { per capita } \\
\text { U.S. dollars }\end{array}$ & $\begin{array}{c}\text { Growth } \\
1996-2000\end{array}$ \\
\hline Andorra & $x$ & & & $\ldots$ & ... & $\cdots$ & 13 \\
\hline Anguilla & $\mathrm{x}$ & & $\mathrm{X}$ & $\ldots$ & $\ldots$ & $\ldots$ & $\ldots$ \\
\hline Antigua and Barbuda & $\mathrm{X}$ & & $\mathrm{X}$ & $\ldots$ & $\ldots$ & $\ldots$ & $\ldots$ \\
\hline Aruba & $\mathrm{X}$ & & $\mathrm{X}$ & 18 & 35 & 2,277 & 76 \\
\hline Bahamas & $\mathrm{x}$ & $\mathrm{x}$ & $\mathrm{X}$ & 433 & 713 & 70,687 & 21 \\
\hline Bahrain & $\mathrm{X}$ & & & 118 & 163 & 12,240 & 40 \\
\hline Barbados & $\mathrm{x}$ & & & 58 & 97 & 5,707 & 148 \\
\hline Bęlize & $\mathrm{x}$ & & $\mathrm{X}$ & $\ldots$ & $\ldots$ & $\ldots$ & 3,470 \\
\hline Bermuda & & & & 980 & ... & 399,095 & 158 \\
\hline British Virgin Islands & $\mathrm{x}$ & & $\mathrm{X}$ & $\ldots$ & $\ldots$ & $\ldots$ & 136 \\
\hline Cayman Islands & & $\mathrm{X}$ & $\mathrm{X}$ & 22,000 & $\ldots$ & $6,600,000$ & 89 \\
\hline Cook Islands & $\mathrm{x}$ & $\mathrm{X}$ & $\mathrm{x}$ & $\ldots$ & .. & $\ldots$ & $\ldots$ \\
\hline Cyprus & & & $\mathrm{x}$ & $\ldots$ & $\ldots$ & $\ldots$ & $\ldots$ \\
\hline Dominica & $x$ & $\mathrm{x}$ & & $\ldots$ & $\ldots$ & $\ldots$ & 1,017 \\
\hline Gibraltar & $\mathrm{x}$ & & & $\ldots$ & ... & $\ldots$ & 377 \\
\hline Grenada & $\mathrm{X}$ & & & $\ldots$ & .. & $\ldots$ & 350 \\
\hline Guemsey/Sark/Aldemey & $\mathrm{X}$ & & & $\ldots$ & ... & $\ldots$ & $\ldots$ \\
\hline Isle of Man & & & & $\ldots$ & .. & $\ldots$ & $\cdots$ \\
\hline Jersey & $\mathrm{X}$ & & & $\ldots$ & ... & $\ldots$ & $\ldots$ \\
\hline Lebanon & & $\mathrm{x}$ & $\mathrm{x}$ & 29 & 14 & 898 & 86 \\
\hline Liberia & $\mathrm{X}$ & & & 439 & 2,142 & 4,785 & 40 \\
\hline Liechtenstein & $x$ & $x$ & $\mathrm{X}$ & $\ldots$ & ... & $\ldots$ & 40 \\
\hline Maldives & $\mathrm{x}$ & & & $\ldots$ & ... & $\ldots$ & 177 \\
\hline Malta & & & & $\ldots$ & ... & $\ldots$ & $\ldots$ \\
\hline Marshall Islands & $\mathrm{X}$ & $\mathrm{X}$ & $\mathrm{X}$ & $\ldots$ & $\ldots$ & $\ldots$ & $\ldots$ \\
\hline Mauritius & & & $\mathrm{X}$ & $\cdots$ & $\ldots$ & $\ldots$ & 201 \\
\hline Monaco & $\mathrm{X}$ & & & $\ldots$ & $\ldots$ & $\cdots$ & $\ldots$ \\
\hline Montserrat & $\mathrm{X}$ & & & $\ldots$ & $\ldots$ & $\ldots$ & $\ldots$ \\
\hline Nauru & $\mathrm{x}$ & $\mathrm{X}$ & $\mathrm{x}$ & $\ldots$ & $\ldots$ & $\ldots$ & -73 \\
\hline Netherlands Antilles & & & $\mathrm{X}$ & 1,106 & 1,491 & 132,050 & 25 \\
\hline Nine & $\mathrm{x}$ & $\mathrm{x}$ & $\mathrm{x}$ & $\ldots$ & $\ldots$ & $\ldots$ & ... \\
\hline Panama & $\mathrm{X}$ & $\mathrm{x}$ & $\mathrm{X}$ & 328 & 367 & 11,681 & 17 \\
\hline Samoa & $\mathrm{X}$ & & $\mathrm{X}$ & $\cdots$ & $\cdots$ & $\ldots$ & 1,300 \\
\hline San Marino & & & & $\ldots$ & $\ldots$ & $\ldots$ & $\ldots$ \\
\hline Seychelles & & & $\mathrm{X}$ & $\ldots$ & ... & $\ldots$ & 800 \\
\hline St. Kitts \& Nevis & $\mathrm{X}$ & $\mathrm{X}$ & $\mathrm{X}$ & $\ldots$ & ... & $\ldots$ & $\ldots$ \\
\hline St. Vincent and Grenadines & $\mathrm{X}$ & $\mathrm{X}$ & $\mathrm{X}$ & $\ldots$ & ... & $+\infty$ & 94 \\
\hline Tonga & $\mathrm{X}$ & & & $\cdots$ & ... & $\cdots$ & $\ldots$ \\
\hline Turks \& Caicos & $\mathrm{X}$ & & $\mathrm{X}$ & $\cdots$ & $\ldots$ & $\cdots$ & 114 \\
\hline US Virgin Islands & $\mathrm{x}$ & & & $\ldots$ & $\ldots$ & $\ldots$ & $\ldots$ \\
\hline Vanuatu & $\mathrm{x}$ & & $\mathrm{X}$ & 33 & 24 & 148 & -84 \\
\hline
\end{tabular}

Source: OECD; FATF; FSF; and BIS.

1/ Uncooperative jurisdictions identified by the FATF also include Israel, the Philippines, and Russia.

$2 /$ List also includes Costa Rica and St. Lucia.

$3 /$ Most recently available data. 


\section{Some Empirical Observations}

73. In addition to the discussion of the Antillean response to recent international policy initiatives, an empirical examination of past trends in the development of OFCs provides another yardstick against which to measure performance and prospects of the Antillean offshore sector. In what follows, an attempt will be made to empirically determine the factors that have contributed to the growth in offshore sector activity, and whether there are any discernible differences in the factors governing offshore performance of the Netherlands Antilles vis-à-vis its competitor jurisdictions. Evidence was found of a relationship between changes in industrial countries' tax policies and the volume of offshore activity. For the Antilles, regional economic performance also seems to matter. It must be stressed, though, that these empirical findings are very tentative because of limitations on data and model specification.

\section{With much of the offshore centers' attraction being derived from their} commitment to confidentiality, if not outright secrecy, relevant data are not readily available and estimates of the size of offshore activity vary a great deal. For example, a widely circulating - if usually unattributed - estimate states that some 50 percent of the world's money supply either resides or passes through these centers (e.g., Hampton and Abbot, 1999 and Francis, 2000). On the other hand, data by the Bank of International Settlements (BIS) indicate that the combined total stock of the claims of reporting banks residing in BIS countries on offshore centers amount to only 5 percent of these countries" broad money. ${ }^{17}$ While much of the discrepancy in the data is attributable to the fluid definition of "offshore" (see above), it nevertheless highlights the difficulties inherent in any empirical investigation.

75. As discussed above, there are several reasons for offshore center activity. In the following, the demand for offshore assets by BIS reporting countries is analyzed. ${ }^{18}$ Given the

${ }^{17}$ These countries comprise Austria, Belgium, Canada, Denmark, Finland, France, Germany, Ireland, Italy, Japan, Netherlands, Spain, Sweden, the United Kingdom, and the US. Offshore centers in the BIS data comprise Aruba, Bahamas, Bahrain, Barbados, Bermuda, Cayman Islands, Hong Kong, Lebanon, Liberia, Netherlands Antilles, Panama, Singapore, Vanuatu, and the British West Indies, and exclude some large jurisdietions like the English Channel Islands as well as certain offshore activities in major onshore financial centers. The BIS data also do not report important "fiduciary" claims which tend not to go through the banking system (see SM/00/136, Supplement 1).

${ }^{18}$ The data on offshore sector activity consists of liabilities to foreign banks reporting to the BIS for the period 1985-2000, taken from the BIS website http://www.bis.org. Other economic data are from the Fund's WEO database. The data on countries' top corporate and individual tax rates are from annual surveys published by Coopers and

Lybrand/Pricewaterhouse Coopers. 
limited data at hand, the analysis will assess the relative importance of (a) offshore assets as just another form of financial assets that investors would wish to hold in their portfolio, (b) tax policy, and (c) economic performance of the region within which offshore centers operate. The relative importance of these factors is estimated for all offshore centers, Caribbean offshore centers, and the Netherlands Antilles. Unfortunately, owing to lack of data, an analysis of the importance of capital controls and asset protection could not be undertaken.

76. In the empirical specification, investor wealth is approximated by the nominal GDP of the BIS reporting countries, or alternatively by their broad money. Broad money may also be used to estimate the degree of substitutability of offshore assets with other elements in the investor's portfolio. Tax policy changes are empirically captured through changes in the top corporate and individual tax rates, weighted by the 1985 GDP of the BIS countries. ${ }^{19}$ The economic stability in the region close to the Netherlands Antilles is measured by the change in the Venezuelan exchange rate. Given the nonstationarity of most of the data series, error correction specifications were used; first, for the change (flow) in offshore centers' liabilities; and, second, in order to obtain an estimate of the relative performance of the Antillean offshore sector in the region, for the Antillean market share.

\section{Overall determinants of offshore sector performance}

77. The importance of industrial country tax policy is significant in all offshore center definitions, with the estimates indicating that a one percentage point increase in BIS reporting countries' top corporate tax rates leads to a 5 to 6 percent (up to 19 percent in the Caribbean centers) increase in inflows to offshore centers (Table 5). For the Netherlands Antilles, tax policy seems to be less important. However, GDP or broad money stocks are not significant in any estimation. The regional economic stability variable is only significant in one specification, but not for the Netherlands Antilles. Finally, the results suggest that the speed of adjustment becomes faster, the smaller the offshore center aggregate, with instantaneous adjustment to equilibrium in the Netherlands Antilles, compared to a 3-4 year period in all offshore sectors combined. ${ }^{20}$

\footnotetext{
${ }^{19}$ Oil prices and dummy variables for the German unification and the Asian crisis were also used as instruments for instrumental variable estimations.

${ }^{20}$ This, could be due to a misspecification imparted by adding the Venezuelan exchange rate into the estimated equations.
} 
Table 5. Netherlands Antilles: Determinants of Offshore Flows

(Error"correction specification; absolute t-statistics in parentheses)

\begin{tabular}{|c|c|c|c|c|c|c|c|c|c|}
\hline \multirow[t]{2}{*}{ Dependent variable } & \multirow[t]{2}{*}{ Equation } & \multicolumn{6}{|c|}{ Independent varjables } & \multicolumn{2}{|c|}{ Statistics } \\
\hline & & Constant & dGDP & $\mathrm{dM} 2$ & dtax & dVER & $\begin{array}{c}\text { Error } \\
\text { correction }\end{array}$ & R squared & D.W. \\
\hline $\mathrm{dOFC}$ & 了 & $\begin{array}{r}0.00 \\
(0.00)\end{array}$ & $\begin{array}{r}0.12 \\
(0.20)\end{array}$ & $\ldots$ & $\begin{array}{l}0.05 * \mathrm{*} \\
(2.48)\end{array}$ & ... & $\begin{array}{c}-0.28 * * \\
(2.76)\end{array}$ & 0.66 & 1.96 \\
\hline dOFC $1 /$ & 2 & $\begin{array}{r}0.00 \\
(0.04)\end{array}$ & $\cdots$ & $\begin{array}{r}-0.10 \\
(0.19)\end{array}$ & $\begin{array}{l}0.06 * * \\
(2.64)\end{array}$ & $\ldots$ & $\begin{array}{l}-0.32 * * \\
(3.02)\end{array}$ & 0.66 & 1.85 \\
\hline dOFCX & 3 & $\begin{array}{r}0.00 \\
{[0.00]}\end{array}$ & $\begin{array}{r}-0.07 \\
(0.20)\end{array}$ & $\ldots$ & $\begin{array}{c}0.06^{*} \\
(3.22)\end{array}$ & $\ldots$ & $\begin{array}{l}-0.34^{*} \\
(3.88)\end{array}$ & 0.62 & 2.52 \\
\hline $\mathrm{dOFCX} 1 /$ & 4 & $\begin{array}{r}0.00 \\
(0.03)\end{array}$ & $\ldots$ & $\begin{array}{r}-0.01 \\
(0.02)\end{array}$ & $\begin{array}{l}0.09 * * \\
(3.82)\end{array}$ & $\ldots$ & $\begin{array}{c}-0.30 * * \\
(3.97)\end{array}$ & 0.63 & 2.66 \\
\hline $\mathrm{dOFCC}$ & 5 & $\begin{array}{r}0.00 \\
(0.00)\end{array}$ & $\begin{array}{r}-0.69 \\
(1.93)\end{array}$ & $\ldots$ & $\begin{array}{r}-0.01 \\
(0.67)\end{array}$ & $\begin{array}{c}0.20 * * \\
(3.54)\end{array}$ & $\begin{array}{c}-1.01 * * \\
(5.76)\end{array}$ & 0.82 & 3.15 \\
\hline dOFCC $\mathrm{H}$ & 6 & $\begin{array}{r}0.00 \\
(0.01)\end{array}$ & $\ldots$ & $\begin{array}{r}-0.19 \\
(0.41)\end{array}$ & $\begin{array}{c}0.12 * * \\
(4.29)\end{array}$ & $\begin{array}{r}0.07 \\
(1.20)\end{array}$ & $\begin{array}{l}-0.75 * * \\
(5.72)\end{array}$ & 0.83 & 3.13 \\
\hline dOFCC & 7 & $\begin{array}{r}0.00 \\
(0.00)\end{array}$ & $\begin{array}{r}0.33 \\
(0.55)\end{array}$ & $\cdots$ & $\begin{array}{l}0.18 * * \\
(4.10)\end{array}$ & $\cdots$ & $\begin{array}{l}-0.20 * * \\
(4.44)\end{array}$ & 0.68 & 2.56 \\
\hline $\mathrm{dOFCC} 1$ & 8 & $\begin{array}{r}0.00 \\
(0.00)\end{array}$ & $\ldots$ & $\begin{array}{r}0.41 \\
(0.70)\end{array}$ & $\begin{array}{l}0.19 * * \\
(3.99)\end{array}$ & $\ldots$ & $\begin{array}{l}-0.19 * * \\
(4.44)\end{array}$ & 0,68 & 2.58 \\
\hline dOFCNA & 9 & $\begin{array}{r}0.00 \\
(0.00)\end{array}$ & $\begin{array}{r}0.17 \\
(0.42)\end{array}$ & $\ldots$ & $\begin{array}{r}0.03 \\
(1.44)\end{array}$ & $\begin{array}{r}0.16 \\
(1.72)\end{array}$ & $\begin{array}{l}-1.56 * \\
(6.16)\end{array}$ & 0.83 & 2.84 \\
\hline dOFCNA $1 /$ & 10 & $\begin{array}{r}0.00 \\
(0.01)\end{array}$ & $\cdots$ & $\begin{array}{r}-0.19 \\
(0.41)\end{array}$ & $\begin{array}{c}0.12 * * \\
(4,29)\end{array}$ & $\begin{array}{r}0.07 \\
(1.20)\end{array}$ & $\begin{array}{l}-0.75 \\
(5.72)\end{array}$ & 0.83 & 3.13 \\
\hline DOFCNA & 11 & $\begin{array}{r}0.00 \\
(0.00)\end{array}$ & $\begin{array}{r}0.21 \\
(0.25)\end{array}$ & $\ldots$ & $\begin{array}{r}-0.07 \\
(1.74)\end{array}$ & $\ldots$ & $\begin{array}{l}-1.27 * * \\
(4.92)\end{array}$ & 0.72 & 1.99 \\
\hline dOFCNA $1 /$ & 12 & $\begin{array}{r}0.00 \\
(0.00)\end{array}$ & $\ldots$ & $\begin{array}{r}0.94 \\
(0.70)\end{array}$ & $\begin{array}{c}-0.02 * * \\
(3.99)\end{array}$ & $\cdots$ & $\begin{array}{l}-1.12^{* *} \\
(4.44)^{*}\end{array}$ & 0.69 & 2.15 \\
\hline
\end{tabular}

Source: Fund staff estimates.

1/ Estimated with instrumental varibles. 


\section{Relative Antillean performance}

\section{With respect to the market share of the Antillean offshore sector some}

interesting patterns emerge (Table 6). BIS countries' tax policy and GDP or broad money are not significant determinants. The failure of industrial country tax policy variable to have an appreciable impact on the market share of the Antillean offshore sector suggests that all offshore sectors are being affected by this variable in roughty the same way. The market share of the Antillean offshore sector in total and in the Caribbean offshore center aggregate appears to be negatively related to Venezuelan currency instability. This contrasts with a prior that would have suggested that the Netherlands Antilles would benefit from instability and the attendant capital flight. The estimated positive relation between Antillean market share and Venezuelan economic stability tends to support the assertion of Antillean offshore actors that the Netherlands Antilles have obtained an increasingly important role as a regional financial services provider,

\section{E. Concluding Remarks}

79. This chapter has looked into issucs pertaining to the development and prospects of the Antillean offshore sector. The picture emerging is one of a sector which, after initial spectacular growth has encountered a number of obstacles. Nevertheless, it has been able to continue to register positive, albeit more moderate, growth. However, the outlook does not appear favorable. Heightened international attention has been directed toward offshore centers' systemic implications for harmful tax competition, money laundering, financial abuse, and overall financial system stability. Such scrutiny can only be expected to increase. While the Antilles have taken a proactive approach in dealing with the more demanding environment - and have achieved some international recognition for their efforts-more will need to be done. Moreover, many of the economic imbalances which have in the past fed offshore sector developments-from inefficient taxation to capital controls-could be disappearing if globalization continues to proceed apace. While all these developments can reasonably be expected to introduce more challenges to the offshore sector, a tentative empirical investigation has also found that some factors could well be working in favor of the Antillean offshore sector, such as its comparatively more sophisticated nature which makes it less vulnerable to tax policy changes in the industrial countries, and ready to benefit from better economic management in the region. 
Table 6. Netherlands Antilles: Determinants of Netherlands Antilles' Offshore Market Share (Ertot-correction specification; absolute $\mathrm{t}$-statistics in parentheses)

\begin{tabular}{|c|c|c|c|c|c|c|c|c|c|}
\hline \multirow[t]{2}{*}{ Dependent variable } & \multirow[t]{2}{*}{ Equation } & \multicolumn{6}{|c|}{ Independent variables } & \multicolumn{2}{|c|}{ Statistics } \\
\hline & & Constant & dGDP & $\mathrm{dM} 2$ & $\mathrm{dtax}$ & dVER & $\begin{array}{c}\text { Error } \\
\text { correction }\end{array}$ & R squared & D.W. \\
\hline ASHNAO & 1 & $\begin{array}{r}0.11 \\
(1.01)\end{array}$ & $\begin{array}{r}-1.47 \\
(0.82)\end{array}$ & $\ldots$ & $\begin{array}{r}-0.15 \\
(1.25)\end{array}$ & $\begin{array}{r}0.10 \\
(0.30)\end{array}$ & $\begin{array}{r}-0.71 \\
(1.54)\end{array}$ & 0.38 & 2.25 \\
\hline dSHNAO $1 /$ & 2 & $\begin{array}{r}0.10 \\
(0.92)\end{array}$ & $\cdots$ & $\begin{array}{r}-0.93 \\
(0.51)\end{array}$ & $\begin{array}{r}-0.15 \\
(1.03)\end{array}$ & $\begin{array}{r}0.12 \\
(0.32)\end{array}$ & $\begin{array}{r}-0.70 \\
(1.39)\end{array}$ & 0.36 & 2.28 \\
\hline ASHNAOX & 3 & $\begin{array}{r}0.00 \\
(0.00)\end{array}$ & $\begin{array}{r}0.82 \\
(1.38)\end{array}$ & $\cdots$ & $\begin{array}{r}0.02 \\
(0.44)\end{array}$ & $\begin{array}{l}-0.16 \\
(2.19)\end{array}$ & $\begin{array}{l}-1.37 \\
(6.68)\end{array}$ & 0.88 & 2.32 \\
\hline dSHNAOX 1 & 4 & $\begin{array}{r}0.00 \\
(0.05)\end{array}$ & $\ldots$ & $\begin{array}{r}0.73 \\
(1.17)\end{array}$ & $\begin{array}{r}0.04 \\
(1.43)\end{array}$ & $\begin{array}{l}-0.22 * * \\
(2.93)\end{array}$ & $\begin{array}{l}-1.27 * * \\
(6.06)\end{array}$ & 0.87 & 2.27 \\
\hline dSHNAOC & 5 & $\begin{array}{r}0.00 \\
(0.00)\end{array}$ & $\begin{array}{c}0.98 * \\
(1.96)\end{array}$ & $\cdots$ & $\begin{array}{r}-0.01 \\
(1.03)\end{array}$ & $\begin{array}{r}-0.12 \\
(1.85)\end{array}$ & $\begin{array}{l}-1.44^{* *} \\
(7.8)\end{array}$ & 0.91 & 2.49 \\
\hline dSHNAOC $1 /$ & 6 & $\begin{array}{r}0,00 \\
(0.05)\end{array}$ & $\cdots$ & $\begin{array}{r}0.90 \\
(1.70)\end{array}$ & $\begin{array}{r}0.03 \\
(1.03)\end{array}$ & $\begin{array}{l}-0.18 * * \\
(2.77)\end{array}$ & $\begin{array}{l}-1.33 * * \\
(7.03)\end{array}$ & 0.90 & 2.32 \\
\hline
\end{tabular}




\section{Data Definition}

OFC: $\quad \log$ (of U.S. dollar value) of offshore liabilities of all BIS defined offshore centers, source BIS

OFCX: $\quad \log$ (of U.S. dollar value) of offshore liabilities of all BIS defined offshore centers, excluding Hong Kong and Singapore, source BIS

OFCC: $\quad \log$ (of U.S. dollar value) of offshore liabilities of all BIS defined offshore centers in the Caribbean, source BIS

OFNA $\log$ (of U.S. dollar value) of offshore liabilities of the Netherlands Antilles, source BIS

GDP: $\quad \log$ of BIS reporting countries US dollar GDP, source WEO

M2: $\quad \log$ of BIS reporting countries US dollar broad money, source WEO

tax: weighted average BIS reporting countries top marginal corporate tax rate, source Pricewaterhouse Coopers

VER: $\quad \log$ of Venezuelan exchange rate (national currency per US dollar), source WEO

d: $\quad$ first differencing operator

SHNAO: OFNA - OFC

SHNAOX: OFNA - OFCX

SHNAOC: OFNA - OFCC 


\section{References}

Cassard, Marcel, 1994, The Role of Offshore Centers in International Financial Intermediation, IMF Working Paper WP/94/107.

Blum, Jack A., 1998, Financial Havens, Banking Secrecy, and Money Laundering, New York, United Nations, (UNDCP Technical Series; Issue 8).

Financial Action Task Force (FATF), 2001, Progress Report on Non-Cooperative Countries and Territories, available at http://www.oecd.org/fatf. ,2001, Public Statement-Progress Report on Non-Cooperative Countries and Territories, February, available at http://www.oecd.org/fatf.

Financial Stability Forum (FSF), 2000, Report of the Working Group on Offshore Centers, available at: http:/www.fsforum.org.

Francis, Julian, 2000, The Bahamas Perspective, Financial Regulator, Vol. 4, No. 4, pp 27-31.

Hampton, Mark P., 1996, The Offshore Interface: Tax Havens in the Global Economy, Macmillan Press.

Hampton, Mark P. and Abbod, Jason (Editors), 1999: Offshore Finance Centers and Tax Havens, Purdue University Press.

OECD, 1998: Harmful Tax Competition: An Emerging Issue. , 2000: Towards Global Tax Cooperation: Report on the 2000 Ministerial Council Meeting and Recommendations by the Committee on Fiscal Affairs.

Spitz, Barry, 2001, International Tax Havens Guide, Harcourt. 
Table 1. Netherlands Antilles: Composition of GDP, 1992-97

(In millions of NA guilders)

\begin{tabular}{|c|c|c|c|c|c|c|}
\hline & 1992 & 1993 & 1994 & 1995 & 1996 & 1997 \\
\hline Enterprises & 2975.1 & 3141.7 & 3379.9 & 3480.8 & 3644.0 & 3789.0 \\
\hline Agticulture & 26.5 & 33.1 & 34.5 & 31.8 & 28.3 & 28.7 \\
\hline Manufacturing & 258.1 & 243.2 & 266.0 & 281.8 & 303.9 & 271.0 \\
\hline Utilities & 157.1 & 135.7 & 121.8 & 165.2 & 168.9 & 194.4 \\
\hline Construction & 227.8 & 237.5 & 237.2 & 286.9 & 314.4 & 330.6 \\
\hline Trade & 783.2 & 786.0 & 845.0 & 841.4 & 924,2 & 926.4 \\
\hline Hotels and restaurants & 169.2 & 199.2 & 208.9 & 224.3 & 173.8 & 163.2 \\
\hline Transport, storage, and communication & 429.3 & 492.1 & 605.0 & 553.4 & 470.6 & 500.1 \\
\hline Financial intermediation & 363.2 & 403.9 & 389.0 & 401.9 & 519.4 & 538.7 \\
\hline Real estate, renting, other business and education & 434,2 & 496.1 & 510.9 & 542.9 & 567.9 & 634.4 \\
\hline Health care and social services & 128.6 & 157.1 & 177.5 & 188.0 & 199.8 & 199.5 \\
\hline Other community and personal services & 143.1 & 120.1 & 171.5 & 155.3 & 167.3 & 196.8 \\
\hline Households employment & 19.7 & 20.3 & 24.0 & 27.0 & 26.7 & 26.9 \\
\hline Minus interest margin banks & 164.9 & 182.6 & 211.4 & 219.1 & 221.2 & 221.7 \\
\hline Government & 601.1 & 669.1 & 714.8 & 743.2 & 778.4 & 748.1 \\
\hline GDP & 3576.2 & 3810.8 & 4094.7 & 4224 & 4422.4 & 4537.1 \\
\hline
\end{tabular}

Source: Data provided by the Antillean authorities. 
Table 2. Netherlands Antilles: Components of Aggregate Demand, 1992-97

(In millions of NA guilders)

\begin{tabular}{|c|c|c|c|c|c|c|}
\hline & 1992 & 1993 & 1994 & 1995 & 1996 & 1997 \\
\hline Total consumption & $2,953.0$ & $3,218.5$ & $3,632.9$ & $3,986.3$ & $3,983.7$ & $3,845.5$ \\
\hline Private consumption & $2,054.3$ & $2,179.1$ & $2,534.0$ & $2,839.0$ & $2,790.7$ & $2,719.5$ \\
\hline Public consurnption & 898.7 & $1,039.4$ & $1,098.9$ & $1,147.3$ & $1,193.0$ & $1,126.0$ \\
\hline Gross fixed investment & 810.1 & 809.8 & 788.4 & 878.8 & $1,085.1$ & 897.9 \\
\hline Private sector & 739.5 & 706.1 & 695.7 & 759.2 & 953.4 & 818.1 \\
\hline Public sector & 70.6 & 103.7 & 92.7 & 119.6 & 131.7 & 79.8 \\
\hline Stockbuilding & 82.1 & 14.3 & 31.7 & -3.0 & 36.8 & 47.4 \\
\hline Total domestic demand & $3,845.2$ & $4,042.6$ & $4,453.0$ & $4,862.1$ & $5,105.6$ & $4,790.8$ \\
\hline Exports of goods and services & $2,862.3$ & $2,945.6$ & $3,066.8$ & $3,042.0$ & $3,100,5$ & $3,218.3$ \\
\hline Imports of goods and services & $3,131.3$ & $3,177.4$ & $3,425.3$ & $3,680.1$ & $3,783.7$ & $3,472.0$ \\
\hline Foreign balance & -269.0 & -326.5 & -358.5 & -638.1 & -683.2 & -253.7 \\
\hline GDP & $3,576.2$ & $3,810.8$ & $4,094.7$ & $4,224.0$ & $4,422.4$ & $4,537.1$ \\
\hline Net factor income from abroad & 157.9 & 157.2 & 126.2 & 444.3 & 112.6 & 114.4 \\
\hline GNP & $3,734.1$ & $3,968.0$ & $4,220.9$ & $4,668.3$ & $4,535.0$ & $4,651.5$ \\
\hline Depreciation & 410.6 & 470.8 & 524.5 & 540.8 & 569.9 & 577,6 \\
\hline Net national income & $3,323.5$ & $3,497.2$ & $3,696.4$ & $4,127.5$ & $3,965.1$ & $4,073.9$ \\
\hline
\end{tabular}

Source: Data provided by the Antillean authorities.

CInternational Monetary Fund. Not for Redistribution 
Table 3. Netherlands Antilles: Selected Indicators of Economic Activity, 1992-2000

(Annual percentage change)

\begin{tabular}{|c|c|c|c|c|c|c|c|c|c|}
\hline & 1992 & 1993 & 1994 & 1995 & 1996 & 1997 & 1998 & 1999 & 2000 \\
\hline \multicolumn{10}{|l|}{ Oil sector } \\
\hline Production & -5.3 & -2.0 & -3.7 & 0.7 & -1.3 & 15.6 & 2.4 & -7.6 & 6.4 \\
\hline Transshipment & 7.6 & 12.0 & 26.1 & 51.9 & -12.1 & 31.5 & -13.9 & -14.4 & 19.7 \\
\hline \multicolumn{10}{|l|}{ Shipping activity $1 /$} \\
\hline Bonaire & 27.9 & 25.0 & 62.3 & 6.3 & -12.0 & 73.2 & -36.5 & -26.0 & 35.3 \\
\hline Curaçao & -7.0 & -5.5 & -1.8 & 2.9 & -0.9 & 20.8 & 13.1 & -11.4 & -0.2 \\
\hline Construction (Curaçao) 2/ & 37.3 & -7.1 & -0.8 & -2.8 & -22.8 & 112.8 & 17.3 & -14.8 & ... \\
\hline \multicolumn{10}{|l|}{ Tourism 3/ } \\
\hline Stay-over tourism & 3.0 & -4.7 & 10.0 & -12.7 & -12.8 & 9.8 & 1.7 & -2.0 & -4.2 \\
\hline Visitor nights & 8.4 & 5.6 & 10.3 & -3.1 & -2.8 & -6.0 & 0.9 & -0.1 & -1.9 \\
\hline Cruise tourism & -3.1 & 30.3 & 3.8 & -16.2 & 12.8 & 33.2 & 0.3 & -24.3 & 43.5 \\
\hline Electricity production & 7.5 & 6.6 & 4.8 & 4.4 & 1.9 & 2.4 & 6.2 & 0.2 & 0.8 \\
\hline
\end{tabular}

Source: Data provided by the Antillean authorities.

1/ Annual tonnage of shipping traffic in Antillean ports.

2/ Value of completed buildings.

$3 /$ Number of visitors. 
Table 4. Netherlands Antilles: Basic Data on Stay-Over Tourism, 1992-2000 1/

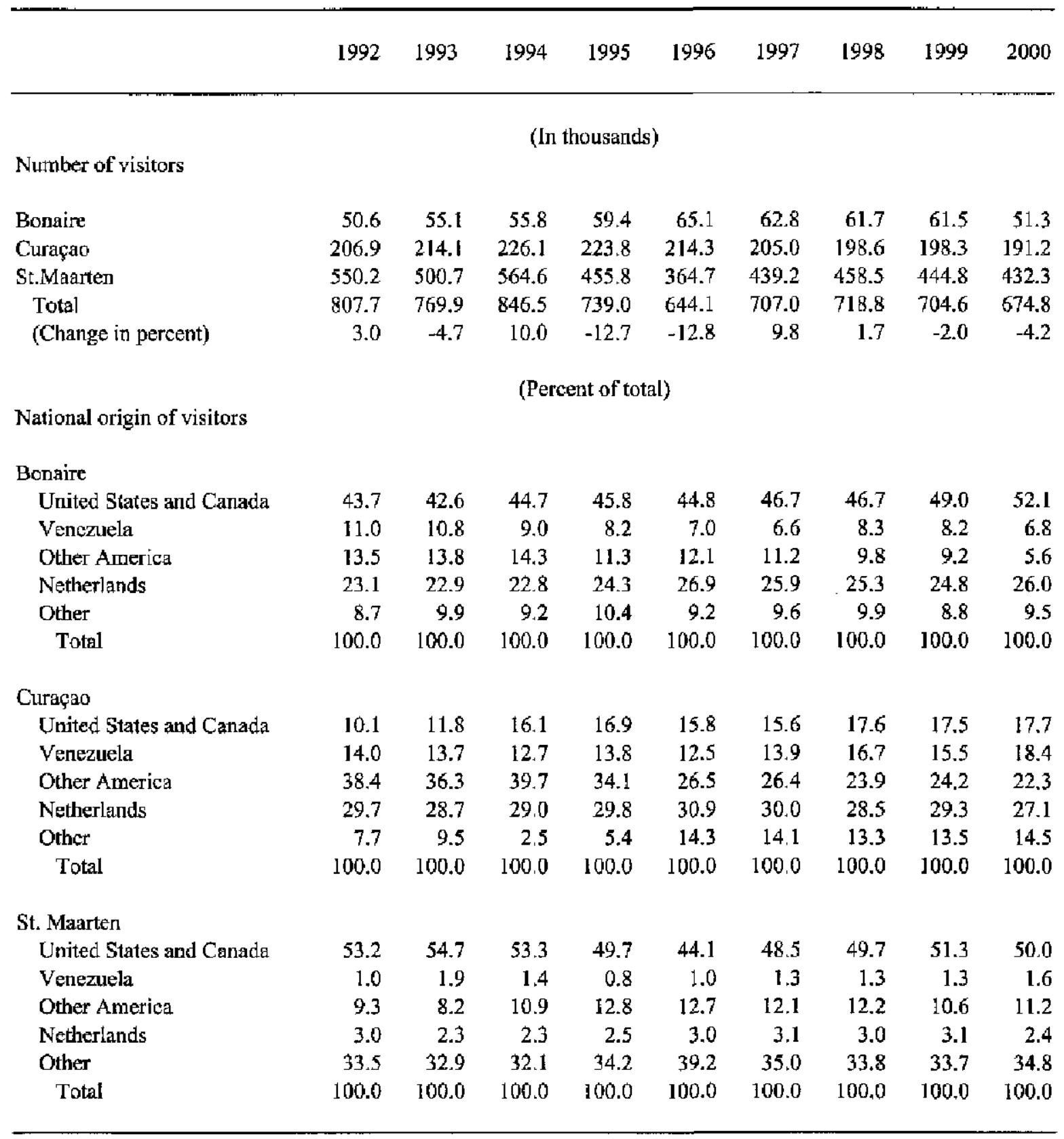

Source: Bank van de Nederlandse Antillen, Quarterly Bulletin.

1/ Foreigners staying longer than 24 hours.

CInternational Monetary Fund. Not for Redistribution 
Table 5. Netherlands Antilles: Cruise Tourism, 1990-2000

(Number of passengers)

\begin{tabular}{rrrrrr}
\hline & Bonaire & Curaçao & St. Maarten & Total & (Change in percent) \\
\hline 1990 & 4,480 & 158,552 & 514,974 & 678,006 & 10.4 \\
1991 & 12,476 & 156,608 & 502,214 & 671,298 & -1.0 \\
1992 & 28,176 & 161,095 & 469,667 & 658,938 & -1.8 \\
1993 & 17,604 & 181,241 & 659,943 & 858,788 & 30.3 \\
1994 & 11,902 & 160,540 & 718,553 & 890,995 & 3.8 \\
1995 & 10,688 & 171,675 & 564,251 & 746,614 & -16.2 \\
1996 & 11,553 & 173,063 & 657,351 & 841,967 & 12.8 \\
1997 & 20,538 & 214,685 & 885,996 & $1,121,219$ & 33.2 \\
1998 & 11,832 & 230,986 & 881,448 & $1,124,266$ & 0.3 \\
1999 & 14,790 & 220,706 & 615,329 & 850,825 & -24.3 \\
2000 & 43,477 & 309,373 & 868,318 & $1,221,168$ & 43.5 \\
\hline
\end{tabular}

Source: Bank van de Nederlandse Antillen, Quarterly Bulletin. 
Table 6. Netherlands Antilles: Changes in Consumer Prices, 1992-2000

(Annual percentage change; period average)

\begin{tabular}{|c|c|c|c|c|c|c|c|c|c|}
\hline & 1992 & 1993 & 1994 & 1995 & 1996 & 1997 & 1998 & 1999 & 2000 \\
\hline \multicolumn{10}{|l|}{ Food } \\
\hline Curaçao & 2.8 & 3,2 & 2.4 & 5,1 & 5.1 & 2.3 & 1.2 & 2.0 & 6.3 \\
\hline Bonaire & 2.8 & 4.2 & 6.0 & 5.4 & 4.5 & 1.7 & 0.2 & 5.7 & 4.0 \\
\hline St. Magrten & 1.5 & 1.3 & 3.8 & 6.4 & 4.9 & 3.0 & 1.5 & 0.2 & $\ldots$ \\
\hline \multicolumn{10}{|l|}{ Beverage and tobacco } \\
\hline Curaçao & 8.7 & 2,7 & 1.2 & 3,0 & 4.0 & 3.7 & 1.1 & 1.4 & 10.2 \\
\hline Bonaire & 10.9 & 12.0 & 7.9 & 1.9 & 0.1 & 2.8 & 5.5 & 4.1 & 5.5 \\
\hline St. Maarten & 2.7 & 1.3 & 0.7 & 0.3 & 4.0 & 1.3 & 4.3 & 0.9 & $\ldots$ \\
\hline \multicolumn{10}{|l|}{ Clothing and footwear } \\
\hline Curaçao & 3.0 & -0.2 & -0.5 & -3.8 & -2.7 & 0.7 & ... & 0.8 & 1.5 \\
\hline Bonaire & 2.0 & 0.0 & 0.0 & 0.1 & 0.1 & $\ldots$ & $\ldots$ & 1.3 & 1.5 \\
\hline St. Maarten & 1.9 & -0.8 & -2.1 & -0.5 & 0.3 & 0.4 & 0.5 & 0.4 & $\ldots$ \\
\hline \multicolumn{10}{|l|}{ Housing } \\
\hline Curaçao & 0.0 & 0.8 & -1.0 & 3.7 & 6.0 & 3.9 & 0.9 & -0.2 & 8.4 \\
\hline Bonaire & 1.4 & 0.0 & 2.1 & 1.8 & 1.9 & 2.4 & 0,5 & 0.4 & 2.1 \\
\hline St. Maarten & 1.9 & 1.7 & 1.4 & 1.7 & 2.5 & 3.6 & 0.9 & 1.8 & $\ldots$ \\
\hline \multicolumn{10}{|l|}{ Housekeeping and furnishing } \\
\hline Curaçao & 1.3 & 2.0 & 5.4 & 3.2 & 1.1 & 2.1 & 0.8 & -1.0 & 0.7 \\
\hline Bonaire & -0.3 & 1.0 & 3.5 & 1.5 & 3.1 & 1.5 & 0.8 & 2.2 & 2.9 \\
\hline St. Maarten & 2.0 & 0.8 & 5.6 & 7.8 & 1.4 & 1.7 & 0.9 & 0.5 & $\ldots$ \\
\hline \multicolumn{10}{|l|}{ Health } \\
\hline Curaçao & 3.2 & 3.7 & 5.6 & 1.7 & 1.5 & 3.3 & 2.3 & 1.4 & 3.8 \\
\hline Bonaire & 5.8 & 2.4 & 3.5 & 4.4 & 5.7 & 3.8 & 0.4 & 2.1 & 0.9 \\
\hline St. Maarten & 0.0 & 1.1 & 2.3 & 1.9 & 1.4 & 0.1 & 1.4 & 3.8 & $\ldots$ \\
\hline \multicolumn{10}{|l|}{ Transport and communication } \\
\hline Curaçao & 1.1 & 3.6 & 2.1 & 2.6 & 5.4 & 4.1 & 1.9 & -0.4 & 7.8 \\
\hline Bonaire & 2.6 & 5.5 & 0.8 & 1.5 & 3.6 & 4.2 & 4.9 & 8.1 & 8.6 \\
\hline St. Maarten & 2.0 & 0.2 & 1.0 & 1.6 & 2.1 & 5,4 & 5.6 & 4.6 & $\ldots$ \\
\hline \multicolumn{10}{|l|}{ Recreation and education } \\
\hline Curaçao & 1.5 & 1.7 & 1.1 & 2.0 & 0.7 & 2.5 & 0.8 & 0.9 & 0.9 \\
\hline Bonaire & 0.5 & 0.1 & 0.9 & 1.0 & 0.9 & 1.9 & 2.2 & 2.0 & 1.0 \\
\hline St. Maarten & 1.3 & 2.9 & 2.0 & 0.9 & 0.6 & 2.5 & 1.1 & 0.4 & $\ldots$ \\
\hline \multicolumn{10}{|l|}{ Other } \\
\hline Curaçao & 1.3 & 2.3 & 4.1 & 2.3 & 2.5 & 4,6 & 1.2 & 1.0 & 5.0 \\
\hline Bonaire & 1.1 & 1.2 & 3.0 & 1.8 & 3.1 & 3.3 & 0.9 & 1.3 & 2.9 \\
\hline St. Maarten & 0.3 & 0.3 & 3.3 & 2.7 & 2.0 & 29 & 1.1 & 1.6 & $\ldots$ \\
\hline \multicolumn{10}{|l|}{ Total } \\
\hline Curaçao & 1.4 & 2.1 & 1,8 & 2.8 & 3.6 & 3.1 & 1.1 & 0.4 & 5.8 \\
\hline Bonaire & 1.9 & 2.2 & 2.9 & 2.4 & 2.7 & 2.3 & 1.3 & 3.4 & 3.5 \\
\hline St. Maarten & 1.7 & 1.0 & 2.1 & 3.0 & 2.3 & 3.1 & 1.9 & 2.0 & $\ldots$ \\
\hline Total Netherlands Antilles & 1.4 & 1.9 & 1.9 & 2.8 & 3.4 & 3.1 & 1.2 & 0.8 & $\ldots$ \\
\hline
\end{tabular}

Sousce: Bank van de Nederlandse Antillen.

CInternational Monetary Fund. Not for Redistribution 
Table 7. Netherlands Antilles: Minimum Wages 1/

(In NA guilders per month)

\begin{tabular}{|c|c|c|c|c|c|c|c|c|c|}
\hline & 1990 & 1991 & 1992 & 1993 & 1994 & 1995 & 1996 & 1997 & 1998 \\
\hline \multicolumn{10}{|c|}{ Catcgory 1 (Manufacturing, construction, banking, financial services, and insurance) } \\
\hline Curaço & 925.40 & 925.40 & 925.40 & 925.40 & $1,000.00$ & $1,000.00$ & $1,000.00$ & $1,000,00$ & $1,000,00$ \\
\hline Bonaire & 925.40 & 925.40 & 925.40 & $1,000.00$ & $1,010.00$ & $1,010.00$ & $1,039.29$ & $1,039,29$ & $1,039.29$ \\
\hline St. Maarten & 925.40 & 925.40 & 925.40 & $1,100.00$ & $1,100.00$ & $1,100.00$ & $1,100.00$ & $1,100,00$ & $1,100,00$ \\
\hline Saba & 925.40 & 925,40 & 925.40 & 925.40 & 950.00 & 950.00 & $1,000,00$ & $1,000.00$ & $1,000.00$ \\
\hline St. Eustatius & 925.40 & 925.40 & 925.40 & 925.40 & 950.00 & 950.00 & 950.00 & 950.00 & 950.00 \\
\hline \multicolumn{10}{|c|}{ Category 2 (Transportation, tourism, and other services) } \\
\hline Curaçao & 686.90 & 686.90 & 686.90 & 775.00 & 850.00 & 850.00 & 900.00 & 900.00 & 900.00 \\
\hline Bonaire & 686.90 & 686.90 & 686,90 & 800.00 & 816.00 & 816.00 & 927.65 & 927.65 & 927.65 \\
\hline St. Maarten & 882.65 & 882.65 & 882.65 & $1,100.00$ & $1,100.00$ & $1,100.00$ & $1,100.00$ & $1,100.00$ & $1,100.00$ \\
\hline Saba & 549.50 & 686.90 & 686.90 & 686.90 & 700.00 & 700.00 & 800.00 & 800.00 & 800.00 \\
\hline St. Eustatius & 549.50 & 686.90 & 686.90 & 686.90 & 700.00 & 700.00 & 700.00 & 700.00 & 700.00 \\
\hline \multicolumn{10}{|c|}{ Category 3 (Agriculture, commerce, and textile industry) } \\
\hline Curaçao & 656.25 & 686.90 & 686.90 & 775.00 & 850.00 & 850.00 & 900.00 & 900.00 & 900.00 \\
\hline Bonaire & 656.25 & 686.90 & 686,90 & 800.00 & 816.00 & 816.00 & 927.65 & 927.65 & 927.65 \\
\hline St. Maarten & 843.25 & 882.65 & 882.65 & $1,100.00$ & $1,100.00$ & $1,100.00$ & $1,100.00$ & $1,100,00$ & $1,100.00$ \\
\hline Saba & 475.95 & 549.50 & 549.50 & 549.50 & 700.00 & 700.00 & 800.00 & 800.00 & 800.00 \\
\hline St. Eustatius & 475.95 & 549.50 & 549.50 & 549.50 & 700.00 & 700.00 & 700.00 & 700.60 & 700.00 \\
\hline \multicolumn{10}{|c|}{ Category 4 (Household personnel) } \\
\hline Curaçao & 355.00 & 355.00 & 355.00 & 400.00 & 420.00 & 420.00 & 470.00 & 470.00 & 470.00 \\
\hline Bonaire & 355.00 & 355.00 & 355.00 & 400.00 & 404.00 & 404.00 & 444.40 & 444.40 & 444.40 \\
\hline St. Maartęn & 355.00 & 355.00 & 355.00 & 425.00 & 425.00 & 500.40 & 500.40 & 500.40 & 500.40 \\
\hline Saba & 355.00 & 355.00 & 355.00 & 400.00 & 400.00 & 400.00 & 550.00 & 550.00 & 550,00 \\
\hline St. Eustatius & 355.00 & 355.00 & 355.00 & 400.00 & 400,00 & 400.00 & 522.72 & 522.72 & 522.72 \\
\hline
\end{tabular}

Source: Data provided by the Antillean authorities.

1/ Youth minimum wages which were introduced on September 1, 1993, are lower. They are expressed as percentages of the regular minimum wages, depending on age levels: 90 percent at age $20 ; 85$ percent at age $19 ; 75$ percent at age 18 ; and 65 percent at age 16 and 17 . 
Table 8. Netherlands Antilles: Employment, Unemployment, and Migration, 1990-2000

\begin{tabular}{|c|c|c|c|c|c|c|c|c|}
\hline & & \multicolumn{4}{|c|}{ Employment (persons) } & \multicolumn{2}{|c|}{ Unemployment rate } & \multirow{2}{*}{$\frac{\text { Migration } 1 /}{\text { (persons) }}$} \\
\hline & & Curaçao & Sint Maarten & Other Islands & Total & Curaçao & Total & \\
\hline 1990 & & 47,515 & 15,240 & 5,402 & 68,157 & 17 & $\ldots$ & $-4,104$ \\
\hline 1991 & & 50,265 & 16,054 & 5,585 & 71,904 & 14.6 & $\ldots$ & $-3,674$ \\
\hline 1992 & & 50,999 & 16,911 & 5,771 & 73,681 & 13.9 & $\ldots$ & $-1,352$ \\
\hline 1993 & & 52,435 & 17,814 & 6,443 & 76,692 & 13.6 & $\cdots$ & -523 \\
\hline 1994 & & 54,685 & 18,718 & 7,172 & 80,575 & 12.8 & $\ldots$ & 317 \\
\hline 1995 & & 54,059 & 18,497 & 8,043 & 80,599 & 13.1 & $\ldots$ & -178 \\
\hline 1996 & & 56,964 & 19,259 & 8,912 & 85,135 & 14 & 14.1 & $-1,296$ \\
\hline 1997 & & 56,246 & 18,896 & 9,366 & 84,508 & 15.3 & 14.9 & 1,531 \\
\hline 1998 & & 52,962 & 18,896 & 9,812 & 81,670 & 16.6 & 15.8 & $-4,607$ \\
\hline 1999 & 21 & $\cdots$ & $\ldots$ & $\ldots$ & $\ldots$ & $\cdots$ & $\cdots$ & $-5,511$ \\
\hline 2000 & 31 & 52,236 & 22,626 & 9,812 & 84,674 & 14.0 & $\ldots$ & $-1,865$ \\
\hline
\end{tabular}

Sources: Central Bureau of Statistics; and Bank van de Nederlandse Antillen.

1/ Net, to the Netherlands, minus=outflow.

2/ No labor force survey was conducted in 1999 owing to resource constraints.

$3 /$ For migration, January through July. 
Table 9. Netherlands Antilles: Operations of the General Government, 1996-2000

(In millions of NA guilders)

\begin{tabular}{|c|c|c|c|c|c|}
\hline & 1995 & 1997 & 1998 & 1999 & 2000 \\
\hline Totat revenue & 1283.6 & 1272.4 & 1274.8 & 1172.0 & 1223.3 \\
\hline Tax revenue & 1084.8 & 1119.5 & 1114.5 & 1036.2 & 1094,4 \\
\hline Taxes on incothe and profits & 659.7 & 617.2 & 607.9 & 564.7 & 511.4 \\
\hline Of which; offshore & 120.0 & 130.0 & 120.0 & 122.7 & 80.5 \\
\hline Taxes on property & 34.4 & 41.0 & 33.7 & 38.8 & 45.5 \\
\hline Taxes on goods and services & 219.9 & 331.1 & 331.9 & 281.4 & 399.0 \\
\hline Of which: sales and turnover tax & 47.8 & 127.7 & 141.8 & 105,7 & 231.8 \\
\hline Taxes on international transactions & {$[62.2$} & 121.8 & 132.5 & 143.5 & 128.1 \\
\hline Other taxes & 8.6 & 8.4 & 8.5 & 7.8 & 10.4 \\
\hline Nontax revenue & 191.2 & 144.8 & 151.2 & 125.7 & 117.7 \\
\hline Capital revenue & 0.9 & 0.4 & 0.1 & 1.3 & 1.3 \\
\hline Grants $1 /$ & 6.7 & 7.7 & 9.0 & 8.8 & 10.0 \\
\hline Total expenditure & 1453.2 & 1416.8 & 1378.5 & 1338.9 & 1367.2 \\
\hline Current expenditure & 1379,4 & 1361.4 & 1367.9 & 1300.0 & 1301.4 \\
\hline Wages and salaries & 716.4 & 687.2 & 645.0 & 626.8 & 562.9 \\
\hline Excl. pension preminiuns & 555.6 & 519.3 & 507.5 & 514.8 & 453.0 \\
\hline Pension premiums $2 /$ & 160.8 & 167.9 & 137.5 & 112.0 & 109.9 \\
\hline Goods and services & 297.0 & 300.9 & 308,9 & 310.8 & 304.2 \\
\hline Subsidjes to enterprises & 97.8 & 89.4 & 77.8 & 64.6 & 61.9 \\
\hline Transfers $1 /$ & 141.1 & 135.7 & 171.0 & 147.7 & 212.6 \\
\hline Of which: to houscholds & & 46.0 & 47.6 & 46.6 & 94.2 \\
\hline Interest payments & 127.1 & 148.3 & 165.2 & \pm 50.1 & 159.7 \\
\hline Capital expenditure & 73.8 & 55.4 & 10.6 & 38.9 & 65.8 \\
\hline Investment & 41,9 & 48.7 & 38.2 & 38.6 & 26.8 \\
\hline Capital transfers and net lending & 31.9 & 6.7 & -27.6 & 0.3 & 39.0 \\
\hline Balance & -169.6 & -144.4 & -103.7 & -166.9 & -143.8 \\
\hline Foneign amortization & 4.6 & 1.9 & 1.9 & 1.9 & 1.9 \\
\hline Balance incl for. amort. & $.174,2$ & -146.3 & -105.6 & -168.8 & -145.7 \\
\hline Financing & 169.6 & 144,4 & 103.7 & 166.9 & 143.8 \\
\hline Domestic & 188.2 & 167.5 & 117.8 & 172.4 & 5.8 \\
\hline Monetary financing & -23.8 & -6.2 & -20.4 & 53.7 & 20.9 \\
\hline Arrears APNA & 14.2 & 89.2 & 18.9 & 85.8 & 16.5 \\
\hline Retroactive bonds & 50.3 & .10 .2 & -10.0 & -10.0 & -10.1 \\
\hline Other domestic & 147.5 & 94.7 & 129.3 & 14.9 & -20.4 \\
\hline Other arrears & 0.0 & 0.0 & 0.0 & 28.0 & -1.1 \\
\hline Other domestic & 197.8 & 84.5 & 119.3 & 4.9 & -30.5 \\
\hline Foreign & -4.6 & -1.9 & -1.9 & -1.9 & 35.0 \\
\hline Amortization payments & -4.6 & -1.9 & -1.9 & -1.9 & -1.9 \\
\hline Debt relief & 0.0 & 0.0 & 0.0 & 0.0 & 0.0 \\
\hline Other foreign & 0.0 & 0.0 & 0.0 & 0.0 & 36.9 \\
\hline Discrepancy/program financing & -14.0 & $-2] .2$ & -12.2 & -3.6 & 103.0 \\
\hline \multicolumn{6}{|l|}{ Metriorandum Items: } \\
\hline Primary balance & -42.5 & 3.9 & 61.5 & -16.8 & 15.9 \\
\hline Balance on cash basis $3 /$ & .155 .4 & -55.2 & -84.8 & -81.1 & -127.3 \\
\hline Debu/GDP tatio & 60.9 & 60.8 & 67.1 & 72.6 & 69.8 \\
\hline Debl & 2691.6 & 2756.8 & 2940.0 & 3155.9 & 3112.3 \\
\hline
\end{tabular}

Sources: Data provided by the Antillean authorities.

1/ Net of ERNA transfers between different levels of govenment.

$2 /$ Pensions premiums due (including non-paid amounts).

3/ Balance based on expenditure excluding accumulated pension premium artears. 
Table 10. Netherlands Antilles: Operations of the Central Government, 1996-2000 (In millions of NA guilders)

\begin{tabular}{|c|c|c|c|c|c|}
\hline & 1996 & 1997 & 1998 & 1999 & 2000 \\
\hline Total revenue & 498.2 & 542.5 & 555.7 & 509.9 & 621.3 \\
\hline Tax revenue & 372.7 & 441.3 & 458.8 & 419.4 & 519.0 \\
\hline Taxes on property & 15.0 & 23.9 & 21.0 & 20.1 & 17.0 \\
\hline Inheritance and gift tax & 2.1 & 4.8 & 8.9 & 5.2 & 2.6 \\
\hline Property transfer tax & 12.9 & 19.1 & 12.1 & 14.9 & 14.4 \\
\hline Taxes on goods and services & 186.9 & 287.2 & 296.8 & 248.0 & 363.5 \\
\hline Of which: excises & 138.3 & 148.6 & 142.6 & 130.7 & 115.1 \\
\hline Excise on gasoline & 96.6 & 108.6 & 104.1 & 93.4 & 79.8 \\
\hline Excise on beer & 16.1 & 15.0 & 14,4 & 13.7 & 13.0 \\
\hline Excise on tobacco & 14.3 & 13.3 & 13.3 & 12.4 & 11.9 \\
\hline Excise on liquor & 11.3 & 11.7 & 10.8 & 11.2 & 10.4 \\
\hline Sales and turnover tax & 41.8 & 127.7 & 141.8 & 105.7 & 231.8 \\
\hline Windward Islands & 0.0 & 31.9 & 40.5 & 27.5 & 33.9 \\
\hline Leeward Islands & 41.8 & 95.8 & 101.3 & 78.2 & 197.9 \\
\hline Licenses & 6.8 & 10.9 & 12.4 & 11.6 & 16.6 \\
\hline Taxes on international transactions & 162.2 & 121.8 & 132.5 & 143.5 & 128.1 \\
\hline Import duties & 150.5 & 118.4 & 131.7 & 142.1 & 126.5 \\
\hline Foreign exchange tax & 9.2 & 0.1 & 0.0 & 0.2 & 0.1 \\
\hline Other & 2.5 & 3.3 & 0.8 & 1.2 & 1.5 \\
\hline Other taxes & 8.6 & 8.4 & 8.5 & 7.8 & 10.4 \\
\hline Stamp taxes & 8.6 & 8.4 & 8.5 & 7.8 & 10.4 \\
\hline Nontax revenue & 118.6 & 93.5 & 87.8 & 81.7 & 92.3 \\
\hline Enterprise and property income & 57.7 & 42.1 & 40.8 & 41.8 & 55.6 \\
\hline Of which: central bank & 45.0 & 38.8 & 32.1 & 41.6 & 43.1 \\
\hline Fees, charges, and sales & 39.9 & 38.3 & 43.5 & 38.9 & 34.7 \\
\hline Other nontax revenues & 21.0 & 13.1 & 3.5 & 1.0 & 2.0 \\
\hline Grants & 6.7 & 7.7 & 9.0 & 8.8 & 10.0 \\
\hline From abroad & 6.1 & 6.9 & 8.3 & 7.7 & 9.1 \\
\hline From other levels of govemment & 0.6 & 0.8 & 0.7 & 1.1 & 0.9 \\
\hline
\end{tabular}


Table 10. (Continued) Netherlands Antilles: Operations of the Central Government, 1996-2000 (In millions of NA guilders)

\begin{tabular}{|c|c|c|c|c|c|}
\hline & 1996 & 1997 & 1998 & 1999 & 2000 \\
\hline Total expenditure & 595.5 & 594.1 & 581.6 & 594.3 & 743.7 \\
\hline Current expenditure & 545.9 & 554.2 & 587.8 & 572.6 & 688.4 \\
\hline Wages and salaries & 317.7 & 308.9 & 289.0 & 296.2 & 262.8 \\
\hline Excl. pension premiurns & 247.6 & 234.5 & 230.0 & 247.9 & 219.9 \\
\hline Wages & 238.9 & 225.2 & 220.9 & 238.2 & 210.5 \\
\hline Soc. security & 8.7 & 9.3 & 9.1 & 9.7 & 9.4 \\
\hline Pension premiums $1 /$ & 70.1 & 74.4 & 59.0 & 48.3 & 42.9 \\
\hline Goods and services & 89.9 & 92.6 & 101.8 & 98.0 & 96.1 \\
\hline Subsidies & 8.3 & 5.5 & 5.0 & 4.4 & 10.8 \\
\hline Transfers & 75.6 & 72.3 & 134.6 & 97.8 & 241.5 \\
\hline Other levels of government & 49.6 & 44.1 & 100.0 & 71.4 & 196.8 \\
\hline Households & 8.8 & 7.2 & 8.7 & 9.6 & 26.8 \\
\hline Non profit institutions, abroad & 17.2 & 21.0 & 25.9 & 16.8 & 17.9 \\
\hline Interest payments & 54.4 & 74.9 & 57.4 & 76.2 & 77.2 \\
\hline Domestic & 48.6 & 60.5 & 62.5 & 71.9 & 83.7 \\
\hline Foreign & 5.8 & 14.4 & -5.1 & 4.3 & -6.5 \\
\hline Capital expenditure & 49.6 & 39.9 & -6.2 & 21.7 & 55.3 \\
\hline Investment & 26,1 & 34.7 & 22.4 & 21.7 & 16.3 \\
\hline Capital transfers & 12.5 & 9.4 & 3.1 & 0.0 & 35.5 \\
\hline Net lending & 11.0 & -4.2 & -31.7 & 0.0 & 3.5 \\
\hline Balance & -97.3 & -51.6 & -25.9 & -84.4 & -122.4 \\
\hline Sinking fund & 0.0 & 0.0 & 0.0 & 0.0 & 0.0 \\
\hline Balance incl. sinking fund & -97.3 & -51.6 & -25.9 & -84.4 & -122.4 \\
\hline Foreign amortization & 1.1 & 0.7 & 0.7 & 0.7 & 0.7 \\
\hline Balance incl for amort. & -98.4 & -52.3 & -26.6 & -85.1 & -123.1 \\
\hline \multicolumn{6}{|l|}{ Memorandum Item: } \\
\hline Balance on cash basis $2 /$ & -81.4 & -33.3 & -59.6 & -37.5 & -108.2 \\
\hline
\end{tabular}

Sources: Data provided by the Antillean authorities.

1/ Pensions premiums due (including non-paid amounts).

2/ Balance based on expenditure excluding accumulated pension premium arrears. 
Table 11. Netherlands Antilles: Operations of the Island Government of Curaçao, 1996-2000 (In millions of NA guilders)

\begin{tabular}{|c|c|c|c|c|c|}
\hline & 1996 & 1997 & 1998 & 1999 & 2000 \\
\hline Total revenue & 808.9 & 748.6 & 764.5 & 703.9 & 757.4 \\
\hline Tax revenue & 712.1 & 678.2 & 655.7 & 616.8 & 575.4 \\
\hline Taxes on income and profits & 659.7 & 617.2 & 607.9 & 564.7 & 511.4 \\
\hline Profit tax & 277.3 & 271.9 & 255.5 & 226.1 & 165.4 \\
\hline Offshore & 120.0 & 130.0 & 120.0 & 122.7 & 80.5 \\
\hline Onshore & 157.3 & 141.9 & 135.5 & 103.4 & 84.9 \\
\hline Wage tax & 339.0 & 316.2 & 329.5 & 324.8 & 335.2 \\
\hline Income tax & 43.4 & 29.1 & 22.9 & 13.8 & 10.8 \\
\hline Taxes on property & 19.4 & 17.1 & 12.7 & 18.7 & 28.5 \\
\hline Land tax & 15.7 & 9.9 & 6.5 & 13.7 & 21.1 \\
\hline Occupency tax & 3.7 & 7.2 & 6.2 & 5.0 & 7.4 \\
\hline Taxes on goods and services & 33.0 & 43.9 & 35.1 & 33.4 & 35.5 \\
\hline Motor vehicle taxes & 18.4 & 23.6 & 20.7 & 19.6 & 25.9 \\
\hline Licenses & 11.6 & 16.3 & 11.5 & 11.4 & 7.2 \\
\hline Hotel room tax & 3.0 & 4.0 & 2.9 & 2.4 & 2.4 \\
\hline Nontax Tevenue & 72.6 & 51.3 & 63.4 & 44.0 & 25.4 \\
\hline Enterprise and property income & 24.0 & 18.3 & 29.7 & 21.0 & 2.7 \\
\hline Fees, charges, and sales & 28.9 & 20.2 & 24.5 & 16.5 & 13.6 \\
\hline Other notitax tevenues & 19.7 & 12.8 & 9.2 & 6.5 & 9.0 \\
\hline Capital revenue & 0.7 & 0.4 & 0.0 & 1.3 & 1.3 \\
\hline Grants & 23.5 & 18.7 & 45.4 & 41.8 & 155.4 \\
\hline
\end{tabular}


Table 11. (Continued) Netherlands Antilles: Operations of the Island Government of Curaçao

(In millions of NA guilders)

\begin{tabular}{|c|c|c|c|c|c|}
\hline & 1996 & 1997 & 1998 & 1999 & 2000 \\
\hline Total expenditure & 881.2 & 841.4 & 842.3 & 786.4 & 778.8 \\
\hline Cutrent expenditure & 857.0 & 825.9 & 825.5 & 769.2 & 768.3 \\
\hline Wages and salaries & 398.7 & 378.3 & 356.0 & 330.6 & 300.1 \\
\hline Excl, pension premiums & 308.0 & 284.8 & 277.5 & 266.9 & 233.1 \\
\hline Pension premiums $1 /$ & 90.7 & 93.5 & 78.5 & 63.7 & 67.0 \\
\hline Goods and services & 207.1 & 208.3 & 207.1 & 212.8 & 208.1 \\
\hline Subsidies & 89.5 & 83.9 & 72.8 & 60.2 & 51.1 \\
\hline Public companies & 89.5 & 83.9 & 72.8 & 60.2 & 51.1 \\
\hline Transfers & 89.0 & 82.1 & 81.8 & 91.7 & 126.4 \\
\hline Other levels of government & 18.0 & 14.4 & 11.4 & 15.2 & 14.0 \\
\hline Households & 40.8 & 38.8 & 38.9 & 37.0 & 67.4 \\
\hline Nonprofit institutions & 30.2 & 28.9 & 31.5 & 39.5 & 45.0 \\
\hline Interest payments & 72.7 & 73.4 & 107.8 & 73.9 & 82.5 \\
\hline Domestic & 60.8 & 72.7 & 87.2 & 64.8 & 73.2 \\
\hline Foreign & 11.9 & 0.7 & 20.6 & 9.1 & 9.3 \\
\hline Capital expenditure & 24.2 & 15.5 & 16.8 & 17.2 & 10.5 \\
\hline Investment & 15.8 & 14.0 & 15.8 & 16.9 & 10.5 \\
\hline Capital transfers & 0.0 & 0.0 & 0.1 & 0.0 & 0.0 \\
\hline Net lending & 8.4 & 1.5 & 0.9 & 0.3 & 0.0 \\
\hline Balance & -72.3 & -92.8 & -77.8 & -82.5 & -21.4 \\
\hline Sinking fund & 0.0 & 0.0 & 0.0 & 0.0 & 0.0 \\
\hline Balance incl. sinking fund & -72.3 & -92.8 & -77.8 & -82.5 & -21.4 \\
\hline Foreign amortization & 3.5 & 1.2 & 1.2 & 1.2 & 1.2 \\
\hline Balance incl. for. amortiz & -75.8 & -94.0 & -79.0 & -83.7 & -22.6 \\
\hline \multicolumn{6}{|l|}{ Memorandum Item: } \\
\hline Balance on cash basis $2 /$ & $-74,0$ & -21.9 & -25.2 & -43.6 & -19.1 \\
\hline
\end{tabular}

Sources: Data provided by the Antillean authorities.

1/ Pensions premiums due (including non-paid amounts).

2/ Balance based on expenditure excluding accumulated pension premium arrears. 
Table 12. Netherlands Antilles: Financing of General Government, 1996-2000 (In millions of NA guilders)

\begin{tabular}{|c|c|c|c|c|c|}
\hline & 1996 & 1997 & 1998 & 1999 & 2000 \\
\hline \multicolumn{6}{|l|}{ Central government } \\
\hline Total balance & -97.3 & -51.6 & -25.9 & -84.4 & -122.4 \\
\hline Financing & 97.3 & 51.6 & 25.9 & 84.4 & 122.4 \\
\hline Domestic financing & 82.7 & 49.7 & 37.2 & 98.7 & 7.1 \\
\hline Monetary financing & -12.8 & 3.6 & 5.2 & 10.4 & 6.8 \\
\hline Central bank & 3.7 & 6.0 & 1.1 & 11.2 & 6.7 \\
\hline Commerical banks & -18.8 & -3.3 & 0.3 & -2.9 & -1.1 \\
\hline Giro Curaçào & 1.5 & 0.0 & 0.0 & 0.0 & 0.0 \\
\hline Coins and notes & 0.8 & 0.9 & 3.8 & 2.1 & 1.2 \\
\hline Non-monetary financing & 95.5 & 46.1 & 32.0 & 88.3 & 0.3 \\
\hline Arrears APNA & 15.9 & 18.3 & -33.7 & 46.9 & 14.2 \\
\hline Retroactive bonds & 22.1 & -4.5 & -4.4 & -4.4 & -4.4 \\
\hline Other domestic financing & 57.5 & 32.3 & 70.1 & 45.8 & -9.5 \\
\hline Loans with the public & 110.4 & 32.3 & 70.1 & 162.6 & -9.5 \\
\hline Debt to SVB & -52.9 & 0.0 & 0.0 & -116.8 & 0.0 \\
\hline Foreign financing & -1.1 & -0.7 & -0.7 & -0.7 & 100.3 \\
\hline Amortization payments & -1.1 & -0.7 & -0.7 & -0.7 & -0.7 \\
\hline Program support. & 0.0 & 0.0 & 0.0 & 0.0 & 64.1 \\
\hline Discrepancy & 15.7 & 2.6 & -10.6 & -13.6 & 15.0 \\
\hline \multicolumn{6}{|l|}{ Curaçao government } \\
\hline Total balance & -72.3 & -92.8 & -77.8 & -82.5 & -21.4 \\
\hline Financing & 72.3 & 92.8 & 77.8 & 82.5 & 21.4 \\
\hline Domestic financing & 105.5 & 117.8 & 80.6 & 73.7 & -1.3 \\
\hline Monetary fuancing & -11.0 & -9.8 & -25.6 & 43.3 & 14.1 \\
\hline Central bank & 11.2 & -3.5 & 1.7 & 21.0 & 55.9 \\
\hline Commerical banks & 51.1 & -6.3 & -27.3 & 22.3 & -41.8 \\
\hline Non-monetary financing & -73.3 & 0.0 & 0.0 & 0.0 & 0.0 \\
\hline Arrears APNA & 116.5 & 127.6 & 106.2 & 30.4 & -15.4 \\
\hline Other arrears & -1.7 & 70.9 & 52.6 & 38.9 & 2.3 \\
\hline Retroactive borlds & 0.0 & 0.0 & 0.0 & 28.0 & $-1,1$ \\
\hline Other domestic financing & 28.2 & -5.7 & -5.6 & -5.6 & -5.7 \\
\hline Loans with the public & 90.0 & 62.4 & 59.2 & -30.9 & -10.9 \\
\hline Debt to SVB & 60.2 & 30.0 & 26.4 & -25.7 & -5.4 \\
\hline Zero coupon bond & 29.8 & 32.4 & 32.8 & -5.2 & -5.5 \\
\hline Foreign financing & -3.5 & -1.2 & -1.2 & -1.2 & 18.8 \\
\hline Amortization payments & -3.5 & -1.2 & -1.2 & -1.2 & -1.2 \\
\hline Program support & 0.0 & 0.0 & 0.0 & 0.0 & 20.0 \\
\hline Discrepancy & -29.7 & -23.8 & -1.6 & 10.0 & 3.9 \\
\hline \multicolumn{6}{|l|}{ General government } \\
\hline Total balance & -169.6 & -144.4 & -103.7 & -166.9 & -143.8 \\
\hline Financing & 169.6 & 144.4 & 103.7 & 166.9 & 143.8 \\
\hline Domestic financing & 188.2 & 167.5 & 117.8 & 172.4 & 5.8 \\
\hline Monetary financing & -23.8 & -6.2 & -20.4 & 53.7 & 20.9 \\
\hline Arrears APNA & 14.2 & 89.2 & 18.9 & 85.8 & 16.5 \\
\hline Other arrears & 0.0 & 0.0 & 0.0 & 28,0 & -1.1 \\
\hline Retroartive bonds & 50.3 & -10.2 & $-10,0$ & -10.0 & -10.1 \\
\hline Other domestic financing & 147.5 & 94.7 & 129.3 & 14.9 & -20.4 \\
\hline Foreign financing & -4.6 & -1.9 & -1.9 & $-1,9$ & 119.1 \\
\hline Amortization payments & -4.6 & -1.9 & -1.9 & -1.9 & -1.9 \\
\hline Program support & 0.0 & 0.0 & 0.0 & 0.0 & 84.1 \\
\hline Other & 0.0 & 0.0 & 0.0 & 0.0 & 36.9 \\
\hline Discrepancy & -14.0 & -21.2 & $-12,2$ & -3.6 & 18.9 \\
\hline
\end{tabular}

Sources: Data provided by the Antillean authorities; and Fund staff estimates. 
Table 13. Netherlands Antilles: General Government Debt, 1996-2000

(lt millions of NA guilders)

\begin{tabular}{|c|c|c|c|c|c|}
\hline & 1996 & 1997 & 1998 & 1999 & 20100 \\
\hline & \multicolumn{5}{|c|}{ Central Government } \\
\hline Domcstic debt & 850.5 & 897.9 & 943.1 & $1,101.4$ & $1,127.5$ \\
\hline Monetary debt & 101.0 & 104.6 & 109.8 & 120.2 & 127.0 \\
\hline Central bank & 37.7 & 43.7 & 44.8 & 56.0 & 62.7 \\
\hline Current account & 5.8 & 6.7 & 2.7 & 3.1 & 2.7 \\
\hline Deposits & 9.0 & 14.6 & 17.1 & 35.5 & 5.3 \\
\hline Advance account & 17.2 & 29.8 & 29.5 & 29.4 & 29.2 \\
\hline Government securitics & 35.3 & 35.2 & 35.1 & 65.2 & 41.5 \\
\hline Commercial banks & 46.5 & 43.2 & 43.5 & 40.6 & 39.5 \\
\hline Current account \& deposits & 36.5 & 45.7 & 46.2 & 30.0 & 34.5 \\
\hline Government securities & 83.0 & 88.9 & 89.7 & 70.6 & 74.0 \\
\hline Coins and noles & 16.8 & 17.7 & 21.5 & 23.6 & 24.8 \\
\hline Non-monetary debt & 749.5 & 793.3 & 833.3 & 981.2 & $1,000.5$ \\
\hline Amears APNA & 22.0 & 40.3 & 6.6 & 53.5 & 86.2 \\
\hline Other domestic debt & 727.5 & 753.0 & 826.7 & 927.7 & 914.3 \\
\hline Government securities & 589.1 & 621.4 & 691.5 & 854.1 & 844.6 \\
\hline Retroactive bonds & 22.1 & 17.6 & $\mathbf{1 3 . 2}$ & 8.8 & 4.4 \\
\hline Negotiated loans $1 /$ & 27.4 & 23.8 & 19.8 & 15.8 & 113 \\
\hline Social Sccurity Fund (SVB) & 78.1 & 74.9 & 72.7 & 8.1 & 25,1 \\
\hline Other & 10.8 & 15.3 & 29.5 & 40.9 & 28.9 \\
\hline Foreign debt & 240.6 & 207.3 & 231.6 & 290.0 & 247.9 \\
\hline Netherlands & 224.1 & 1932 & 216.8 & 195.5 & 190.1 \\
\hline Central government & 223.8 & 1932 & 216.8 & 195.5 & 190.1 \\
\hline Public companies & 0.3 & 0.0 & 0.0 & 0.0 & 0.0 \\
\hline European Union & 16.5 & 14.1 & 14.8 & 12.2 & 10.8 \\
\hline \multirow[t]{2}{*}{ Other } & 0.0 & 0.0 & 0.0 & 82.3 & 47.0 \\
\hline & \multicolumn{5}{|c|}{ Island Government of Curagao } \\
\hline Domestic ảebt & $1,174.3$ & $1,283.2$ & $1,371,4$ & $1,426.6$ & $1,425.0$ \\
\hline Monelary debt & 112.7 & 102.9 & 77.3 & 120.6 & 134.7 \\
\hline Central bank & -4.3 & -7.8 & -6.1 & 14.9 & 70.8 \\
\hline Gurrent account & 4.3 & 7.8 & 21.1 & 0.1 & 0.0 \\
\hline Govermment securities & 0.0 & 0.0 & 15.0 & 15.0 & 70.8 \\
\hline Commercial banks & 117.0 & 110.7 & 83.4 & 105.7 & 63.9 \\
\hline Current account & 38.4 & 27.9 & 34.4 & 17.5 & 35.9 \\
\hline Deposils & 3.] & 4.2 & 3.7 & 3.7 & 1.3 \\
\hline Govemment securities & 158.5 & 142.8 & 121.5 & 126.9 & 101.1 \\
\hline Non-monetary debt & $1,061.6$ & $1,180,3$ & $1,294.1$ & $1,306.0$ & $1,290.3$ \\
\hline Artears APNA & 146.0 & 216.9 & 269.5 & 308.4 & 310.7 \\
\hline Zcoo coupon bond/aturuity & 381.3 & 413.7 & 446.5 & 441.3 & $4,3.5 .8$ \\
\hline Other domestic dobi & 534.3 & 549.7 & 578.1 & 556.3 & 543.8 \\
\hline Government securities & 317.7 & 347.7 & 374.1 & 348.4 & 343.0 \\
\hline Retroactive bonds & 28.2 & 22.5 & 16.9 & 11.3 & 5.6 \\
\hline Social Securily Fund (SVB) & 9.2 & 24.8 & 43.0 & 17.0 & 34.1 \\
\hline Other & 179.2 & 154.7 & 144.1 & 179.6 & $16: 1$ \\
\hline Foreign dcht & 426.7 & 368.4 & 393.9 & 337.9 & 311,9 \\
\hline Netherlands & 417.5 & 360.0 & 383.8 & 329.6 & 304.6 \\
\hline \multirow[t]{2}{*}{ European Union } & 9.2 & 8.4 & 10.1 & 8.3 & 7.3 \\
\hline & \multicolumn{5}{|c|}{ General Govetrument } \\
\hline Domestic dabt & $2,024.8$ & $2,181.1$ & $2,314.5$ & $2,528.0$ & $2,5.52 .5$ \\
\hline Monetary debt & 213.7 & 207.5 & 187.1 & 240.8 & 261.7 \\
\hline Central bank & 33.4 & 35.9 & 38.7 & 70.9 & 133.5 \\
\hline Commercial banks & 163.5 & 153.9 & 126.9 & 146.3 & 103.4 \\
\hline Coins and notes. & 16.8 & 17.7 & 21.5 & 23.6 & 24.8 \\
\hline Non-monetary debt & $1,811.1$ & $1,973.6$ & $2,127.4$ & $2,287.2$ & $2,290.8$ \\
\hline Arrears APNA & 168.0 & 257.2 & 276.1 & 361.9 & 396.9 \\
\hline Zero coupon bond/annuity & 381.3 & 413.7 & 446.5 & 441.3 & 435.8 \\
\hline Other domestic debt & $1,261.8$ & $1,302.7$ & 1.404 .8 & $1,484.0$ & $1,458.1$ \\
\hline Foreign debt & 667.3 & 575.7 & 625.5 & 627.9 & 559.8 \\
\hline Netherlands & 641.6 & $\$ 53.2$ & 600.6 & 525.1 & 494.7 \\
\hline European Union & 25.7 & 22.5 & 24.9 & 20.5 & 18.1 \\
\hline Other & 0.0 & 0.0 & 0.0 & 82.3 & 47.0 \\
\hline
\end{tabular}

Sounce: Datn provided by the Antillean authorities.

1/ APNA Regentesselan, APNA FZOG and Winkel Broth. 
Table 14. Netherlands Antilles: Monetary Survey, 1992-2000

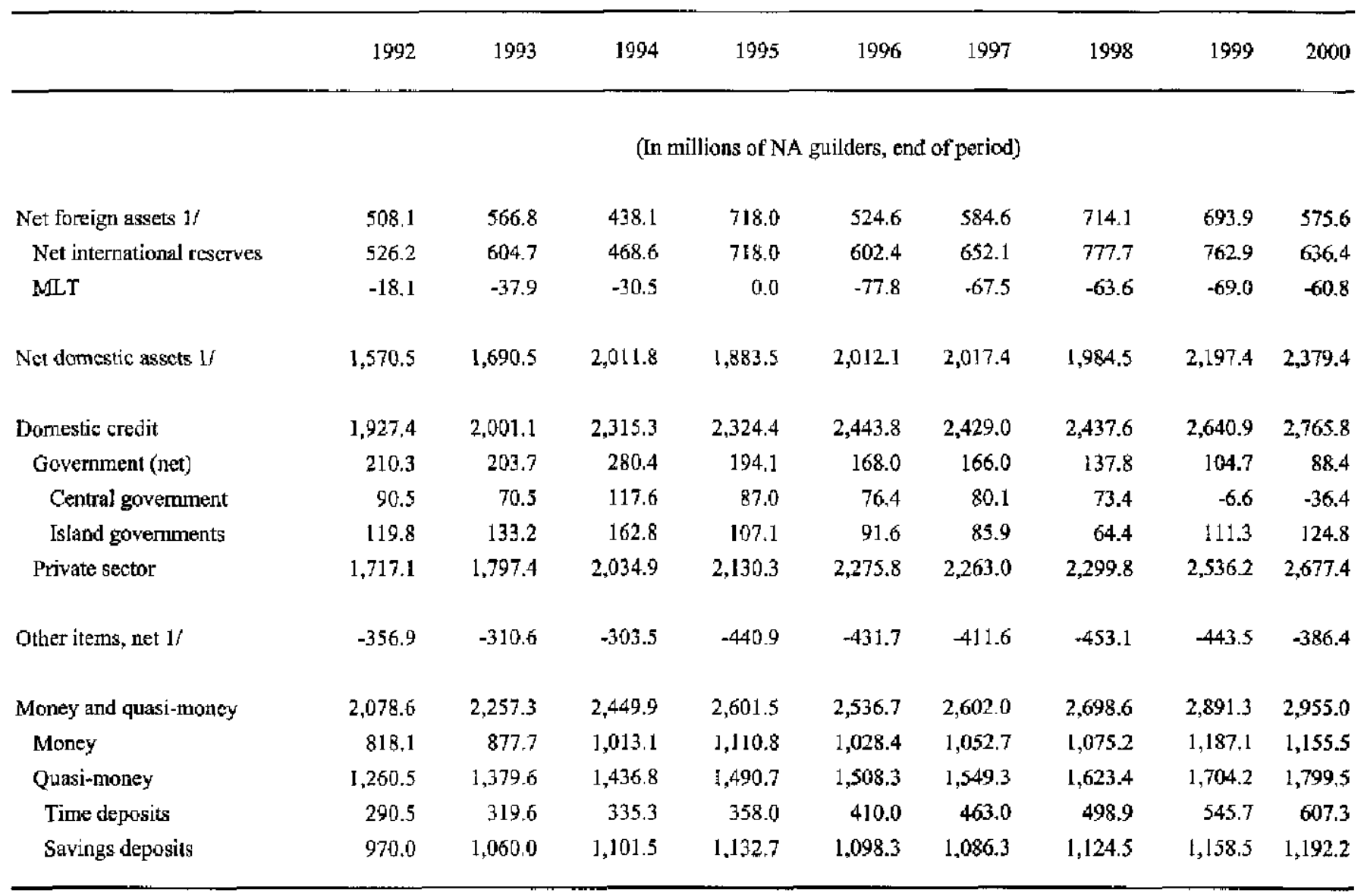

Source: Data provided by the Antillean authorities.

1/ Idcludes gold revatuations from NA f. 67.5 million to NA f. 208.8 million in June 1995, to NA f. 189.5 million in January 1996 to NA f. 179.8 million in November 1998, and to NA f. 138.9 million in December 2000. 
Table 15. Netherlands Antilles: Commercial Bank Credit to the Private Sector, 1992-2000

\begin{tabular}{|c|c|c|c|c|c|c|c|c|c|}
\hline & 1992 & 1993 & 1994 & 1995 & 1996 & 1997 & 1998 & 1999 & 2000 \\
\hline & \multicolumn{9}{|c|}{ (In millions of NA guilders, end of period) } \\
\hline Loaris to the private sector & $1,661.4$ & $1,732.5$ & $1,958.3$ & $2,046.4$ & $2,171.6$ & $2,198.6$ & $2,232.4$ & $2,450.7$ & $2,612.0$ \\
\hline Mortgage & 544.6 & 617.8 & 743.2 & 782.9 & 865.7 & 925.7 & 890.3 & 972.8 & $1,027.9$ \\
\hline Of which: MLT on-lent $1 /$ & 18.1 & 37.9 & 30.5 & 0.0 & 53.7 & 48.7 & 44.8 & $\ldots$ & $\ldots$ \\
\hline Consumer & 283.3 & 381.1 & 451.9 & 485.9 & 507.7 & 478.1 & 516.2 & 570.0 & 622.4 \\
\hline Business & 833.5 & 733.6 & 763.2 & 777.6 & 798.2 & 794.8 & 825.9 & 907.9 & 961.7 \\
\hline \multirow[t]{2}{*}{ Of Which: MLT on-lent 2/ } & 0.0 & 0.0 & 0.0 & 0.0 & 26.9 & 18.8 & 18.8 & $\ldots$ & $\ldots$ \\
\hline & \multicolumn{9}{|c|}{ (Change in percent over end of previous year) } \\
\hline Loans to the private sector & 1.9 & 4.3 & 13.0 & 4.5 & 6.1 & 1.2 & 1.5 & 9.8 & 6.6 \\
\hline Mortgage & -3.2 & 13.4 & 20.3 & 5.3 & 10.6 & 6.9 & $-3,8$ & 9.3 & 5.7 \\
\hline Consumer & 27.7 & 34.5 & 18.6 & 7.5 & 4.5 & -5.8 & 8.0 & 10.4 & 9.2 \\
\hline Business & -1.4 & -12.0 & 4.0 & 1.9 & 2.6 & -0.4 & 3.9 & 9.9 & 59 \\
\hline
\end{tabular}

Source: Data provided by the Antillean authorities.

1/ All mortgage borrowings have been accrued to entities on the Windward Islands.

$2 /$ All business borrowings have been accrued to entities on the Leeward Islands. 
Table 16. Netherlands Antilles: Interest Rates, 1992-2000

(In percent, end of period)

\begin{tabular}{|c|c|c|c|c|c|c|c|c|c|}
\hline & 1992 & 1993 & 1994 & 1995 & 1996 & 1997 & 1998 & 1999 & 2000 \\
\hline Official discount rate & 6.0 & 5.0 & 5.0 & 6.0 & 6.0 & 6.0 & 6.0 & 6.0 & $\ldots$ \\
\hline \multicolumn{10}{|l|}{ Deposit rates } \\
\hline Passbook savings & 4.8 & 4.1 & 4.0 & 3.6 & 3.6 & 3.5 & 3.6 & 3.6 & 3.8 \\
\hline Time deposits $1 /$ & 5.9 & 5.1 & 4.7 & 4.7 & 5.0 & 5.1 & 5.2 & 4.9 & 4.8 \\
\hline \multicolumn{10}{|l|}{ Lending rates } \\
\hline Prime rate $2 /$ & 12.0 & 12.6 & 12.7 & 13.0 & 13.4 & 14,0 & 13.9 & 10.7 & 9.6 \\
\hline Mortgage rate & 12.0 & 12.1 & 11.0 & 11.2 & 11.5 & 12,0 & 11.7 & 10.7 & 10.6 \\
\hline Treasury bill tate $3 /$ & 5.9 & 4.3 & 5.4 & 5.7 & 5.7 & 5.9 & 5.7 & 6.3 & 6.3 \\
\hline Government bond yield 4 & 8.6 & 7.9 & 8.0 & 8.3 & 8.3 & 9.0 & 7.8 & 8.8 & 9.0 \\
\hline \multicolumn{10}{|l|}{ Memorandum item; } \\
\hline Penalty rate & $3.55 t$ & 3.061 & 3.0 & $3.57 /$ & 5,2581 & $5.25-7.0$ & $\begin{array}{r}5.25-7.0 \quad 9 / \\
3.5-5.2510 / \\
2.1-3.511 /\end{array}$ & $2.1-3.5$ & $7.012 /$ \\
\hline
\end{tabular}

Souree: Data provided by the Antillean authorities.

1/ 6-month time deposits reported for 1990-91, 12-month time deposits thereafter.

2/ Prime rate for 1992-1999, current account overdrafts thereafter.

$3 /$ Rate on three-month treasury bills.

4/ Effective yield on five-year government bonds.

$5 /$ In effect from $9 / 199$ t to $4 / 1993$.

6/ In effect from $4 / 1993$ to $3 / 1995$, when MCR in effect.

$7 /$ In effect from $3 / 1995$ to $4 / 1995$.

$8 /$ In effect from $4 / 1995$ to $12 / 1996$.

$9 /$ In effect through $9 / 1998$.

10/ In effect in 10/1998.

11/ In effect from $11 / 1998$ to $12 / 1998$.

$12 /$ In effect from $11 / 2000$. 
Table 17. Netherlands Antilles: Structure and Performance of the Banking System, 1994-2000

$\begin{array}{lllllll}1994 & 1995 & 1996 & 1997 & 1998 & 1999 & 2000\end{array}$

Number of licensed banks

Of which: Majority state owned

As a percentage of total assets

Majority foreign owned (number)

As a percentage of total assets

Number of branches of foreign banks

As a percentage of total assets

Number of Banks accounting for:

25 percent of total assets

75 percent of total assets

Total assets

Total credit

Private sector credit

Total deposits excluding interbank

Corporate sector credit (in percent of total credit) $1 / 2 /$

Credit to households (in percent of total credit) $1 / 2 /$

$\begin{array}{rrrrrrr}13 & 13 & 14 & 14 & 14 & 11 & 11 \\ \text { n.a } & \text { n.a } & 1 & 1 & 1 & 1 & 1 \\ \text { n.a } & \text { n.a } & 3 & 3.5 & 3.8 & 5.0 & 5.6 \\ 2 & 2 & 2 & 2 & 2 & 2 & 2 \\ 0.7 & 1.2 & 3.6 & 5.7 & 5.4 & 7.1 & 7.4 \\ 4 & 4 & 4 & 4 & 4 & 3 & 3 \\ 21.5 & 26.1 & 25.9 & 24.5 & 24.9 & 22.9 & 23.1 \\ & & & & & & \\ 1 & 1 & 1 & 1 & 1 & 1 & 1 \\ 4 & 4 & 4 & 4 & 4 & 4 & 4\end{array}$

(In percent of GDP, unless stated otherwise)

$\begin{array}{lllllll}95.6 & 83.2 & 81.9 & 80.8 & 87.8 & 93.3 & 98.1 \\ 53.3 & 52.9 & 55.1 & 53.6 & 55.9 & 61.0 & 62.5 \\ 47.8 & 48.4 & 49.6 & 48.5 & 51.1 & 56.5 & 58.6 \\ 53.7 & 56.3 & 54.7 & 54.9 & 59.0 & 63.1 & 63.8 \\ 56.3 & 54.8 & 56.3 & 55.7 & 55.2 & 56.1 & 55.7 \\ 39.1 & 41.5 & 40.9 & 42.6 & 42.9 & 41.4 & 41.1\end{array}$

(In percent of total assets)

Foreign currency denominated

Assets
Balance sheet liabilities

Contingent and off-balance sheet accounts

Risk-weighted capital/asset ratio

Central bank credit to banks (in percent of GDP)

Average pretax profit on total assets

Nonperforming loans (in percent of total loans)

Provision for loan losses (in percent of nonperforming loans)

Money (M2) (change in percent, end of period)

Private sector credit (change in percent, end of period) $1 /$

Average lending spread (lending-deposit rate) 3/

\begin{tabular}{rrrrrrr}
44.3 & 35.5 & 33.1 & 31.7 & 32.4 & 32.2 & 34.7 \\
43.9 & 33.8 & 31.1 & 29.8 & 29.1 & 30.5 & 32.9 \\
8.0 & 11.6 & 8.8 & 9.3 & 8.6 & 8.8 & 7.4 \\
& \multicolumn{5}{c}{ (In percent) }
\end{tabular}

$\begin{array}{rrrrrrr}10.6 & 7.0 & 9.1 & 10.7 & 8.4 & 10.3 & 8.9 \\ 0.0 & 0.0 & 0.0 & 0.0 & 0.3 & 1.4 & 1.3 \\ -5.0 & -5.6 & 7.9 & 6.8 & 3.9 & 1.4 & 1.5\end{array}$

$\begin{array}{lllllll}2.3 & 3.0 & 3.1 & 3.4 & 4.3 & 4.1 & 4.7\end{array}$

$\begin{array}{lllllll}166 & 138 & 110 & 122 & 68 & 83 & 76\end{array}$

$\begin{array}{rrrrrrr}8.5 & 6.2 & -2.5 & 2.6 & 3.7 & 7.1 & 2.2 \\ 13.2 & 4.7 & 6.8 & -0.6 & 1.6 & 10.3 & 5.6 \\ 8.0 & 8.3 & 8.4 & 8.9 & 8.7 & 5.8 & 4.8\end{array}$

Source: Bank van de Nederlandse Antillen.

1/ Extended by commercial banks only.

2/ Corporate sector: business loans + other mortgages. Households: consumer loans + individual mortgages.

3/ Interest rate on working capital loans - time deposit rate. Interest rates for prime borrowers are usually about two percentage points less, but no consistent time series is available. From I2/1999 lending rate is current account overdrafts. 
Table 18. Nonbank Financial Intermediation: Insurance companies, 1994-99

(In millions of NA guilders)

\begin{tabular}{|c|c|c|c|c|c|c|}
\hline & 1994 & 1995 & 1996 & 1997 & 1998 & 1999 \\
\hline \multicolumn{7}{|l|}{ Life Insurance } \\
\hline Assets & 716.0 & 803.4 & 898.0 & 960.2 & 1037.8 & $1,158.0$ \\
\hline Curnent & 111.7 & 117.0 & 133.6 & 162.1 & 155.6 & 214.2 \\
\hline Bonds and fixed income & 329.9 & 373.3 & 347.7 & 348.3 & 326.4 & 326.1 \\
\hline Mortgages & 82.4 & 104,1 & 87.7 & 95.5 & 160.0 & 174,9 \\
\hline Other loans & 46.4 & 43.2 & 50.6 & 57.6 & 75.2 & 69.7 \\
\hline Equity & 8.9 & 17.5 & 29.7 & 42.5 & 61.3 & 87.5 \\
\hline Bank deposits & 27,2 & 22.7 & 24.5 & 17.8 & 73.5 & 87.8 \\
\hline Other & 155,9 & 168.8 & 274.8 & 294.0 & 261.0 & 267.5 \\
\hline Capital and reserves & 29.2 & 38.9 & 48.3 & 41.4 & 49,6 & 97.6 \\
\hline \multicolumn{7}{|l|}{ Nón-Life Insurance } \\
\hline Assets & 249.6 & 395.6 & 442.1 & 456.0 & 442.8 & 297.2 \\
\hline Current & 156.8 & 316.3 & 351.2 & 334.7 & 319.1 & 159.7 \\
\hline Bonds and fixed income & 45.2 & 46.6 & 45.8 & 54.5 & 51.9 & 52.1 \\
\hline Mortgages & 0.5 & 0.5 & 4.8 & 3.0 & 0.8 & 0.5 \\
\hline Other loans & 5.6 & 5.8 & 2.0 & 6.0 & 7.1 & 14.0 \\
\hline Equity & 3.8 & 1.7 & 4.0 & 6.8 & 10.3 & 13.6 \\
\hline Bank deposits & 24.5 & 12.0 & 13.3 & 31.3 & 42.5 & 46.7 \\
\hline Other & 13.2 & 12.7 & 21.0 & 19.7 & 11.1 & 10.6 \\
\hline Capital and reserves & 51.1 & 46.3 & 50.0 & 50.2 & 59.1 & 72.6 \\
\hline
\end{tabular}

Source: Bank van de Nederlandse Antillen. 
Table 19. International Financial Sector, 1994-2000

(In million of NA guilders)

\begin{tabular}{lrrrrrrr}
\hline & 1994 & 1995 & 1996 & 1997 & 1998 & 1999 & 2000 \\
\hline Banks & & & & & & & \\
$\quad$ Assets & 52,182 & 55,621 & 57,582 & 64,885 & 65,209 & 58,697 & 61,693 \\
Demand deposits & 2,521 & 8,765 & 3,859 & 2,910 & 3,398 & 3,419 & 3,751 \\
Time deposits & 8,023 & 13,904 & 12,802 & 17,278 & 16,863 & 15,239 & 14,580 \\
Borrowed funds & 36,159 & 26,150 & 34,217 & 37,795 & 38,092 & 33,907 & 36,837 \\
Equity & 1,497 & 4,604 & 3,940 & 4,278 & 4,757 & 4,945 & 5,450 \\
& & & & & & & \\
Life insurance & 29 & 32 & 37 & 38 & 44 & 38 & $\ldots$ \\
Assets & 5 & 6 & 4 & 6 & 4 & 7 & $\ldots$ \\
Capital & 13 & 17 & 23 & 22 & 25 & 21 & $\ldots$ \\
Reserves & & & & & & & \\
& & & & & & & \\
Non-life insurance & 777 & 924 & 1,232 & 1,631 & 2,030 & 2,166 & $\ldots$ \\
Assets & 129 & 133 & 130 & 156 & 126 & 122 & $\ldots$ \\
Capital & 252 & 376 & 514 & 739 & 896 & 1,017 & $\ldots$ \\
Reserves & & & & & & & \\
\hline
\end{tabular}

Source: Bank van de Nederlandse Antillen. 
Table 20. Netherlands Antilles: Balance of Payments, 1996-2000

(In millions of NA guilders)

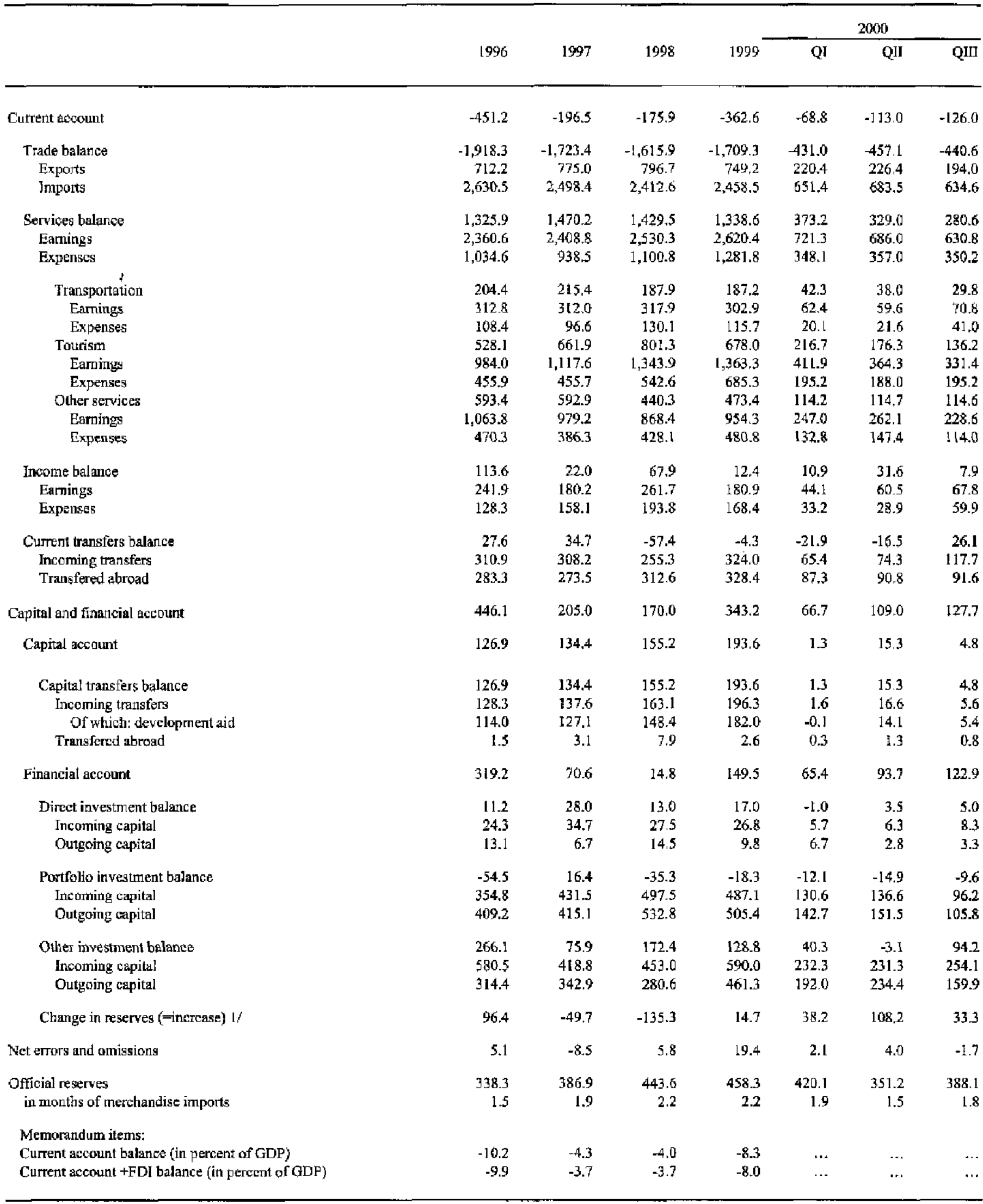

Source: Data provided by the Antillean authotities.

1/ Including commercial banks, excluding gold rcvaluation. 
Table 21. Netherlands Antilles: Current Inflows (Cash Basis), 1995-99

(In millions of NA guilders)

\begin{tabular}{|c|c|c|c|c|c|}
\hline & 1995 & 1996 & 1997 & 1998 & 1999 \\
\hline Merchandise exports & 632 & 712 & 775 & 797 & 749 \\
\hline Curacao and Bonaire & 442 & 469 & 578 & 634 & 509 \\
\hline Windward Islands & 190 & 243 & 197 & 163 & 240 \\
\hline Nonfactor services & 2,444 & 2,361 & 2,409 & 2,530 & 2,621 \\
\hline Tourism & 1,005 & 984 & 1,118 & 1,344 & 1,363 \\
\hline Curaçao and Bonaire & 380 & 408 & 439 & 546 & 559 \\
\hline Windward Islands & 624 & 576 & 678 & 798 & 805 \\
\hline Refining & 265 & 269 & 207 & 207 & 194 \\
\hline Offshore sector & 551 & 550 & 523 & 459 & 457 \\
\hline $\begin{array}{l}\text { Operating income } \\
\text { Other }\end{array}$ & 551 & 550 & 523 & 459 & 457 \\
\hline Transportation & 313 & 313 & 312 & 318 & 303 \\
\hline Storage & 88 & 75 & 74 & 82 & 80 \\
\hline Passenger fares & 89 & 104 & 98 & 103 & 118 \\
\hline Other & 137 & 133 & 140 & 133 & 105 \\
\hline Other services & 310 & 246 & 250 & 203 & 303 \\
\hline $\begin{array}{l}\text { Total merchandise exports } \\
\text { and nonfactor services }\end{array}$ & 3,076 & 3,073 & 3,184 & 3,327 & 3,370 \\
\hline Investment income & 209 & 242 & 180 & 262 & 181 \\
\hline Current transfers & 653 & 311 & 308 & 255 & 324 \\
\hline Profit taxes & 249 & 164 & 147 & 115 & 124 \\
\hline Total current inflows & 3,938 & 3,626 & 3,672 & 3,844 & 3,875 \\
\hline
\end{tabular}

Source: Data provided by the Antillean authorities.

CInternational Monetary Fund. Not for Redistribution 
Table 22. Netherlands Antilles: Current Outflows (Cash Basis), 1995-99

(In millions of NA guilders)

\begin{tabular}{lrrrrr}
\hline & 1995 & 1996 & 1997 & 1998 & 1999 \\
\hline Merchandise imports & 2,565 & 2,631 & 2,498 & 2,413 & 2,459 \\
$\quad \begin{array}{l}\text { Curaçao and Bonaire } \\
\text { Windward Islands }\end{array}$ & 1,726 & 1,794 & 1,792 & 1,757 & 1,738 \\
& 839 & 836 & 707 & 655 & 721 \\
Nonfactor services & 966 & 1,035 & 939 & 1,101 & 1,282 \\
$\quad$ Tourism & 397 & 456 & 456 & 543 & 685 \\
$\quad$ Curaçao and Bonaire & 290 & 338 & 338 & 358 & 367 \\
$\quad$ Windward Islands & 107 & 118 & 117 & 185 & 318 \\
$\quad$ Transportation & 110 & 108 & 97 & 130 & 116 \\
Offshore & 200 & 245 & 208 & 181 & 181 \\
$\quad$ Operating expenses & 200 & 245 & 208 & 181 & 181 \\
Other services & 260 & 226 & 178 & 247 & 300 \\
Total merchandise imports & & & & & 3,740 \\
and nonfactor services & 3,531 & 3,665 & 3,437 & 3,513 & 3,740 \\
Investment income & 178 & 128 & 158 & 194 & 168 \\
Current transfers & 284 & 283 & 274 & 313 & 328 \\
Total current outflows & 3,993 & 4,077 & 3,869 & 4,020 & 4,237 \\
\hline
\end{tabular}

Source: Data provided by the Antillean authorities. 
Table 23. Netherlands Antilles: Capital Account (Cash Basis), 1995-99

(In millions of NA guilders)

\begin{tabular}{|c|c|c|c|c|c|}
\hline & 1995 & 1996 & 1997 & 1998 & 1999 \\
\hline Capital transfers balance & $11 t$ & 127 & 135 & 155 & 194 \\
\hline Incoming transfers & 120 & 128 & 138 & 163 & 196 \\
\hline Of which: Development aid & 110 & 114 & 127 & 148 & 182 \\
\hline Transfered abroad & 9 & 2 & 3 & 8 & 3 \\
\hline Capital account balance & 111 & 127 & 135 & 155 & 194 \\
\hline Direct investment balance & -3 & 11 & 28 & 13 & 17 \\
\hline Portfolio investment balance & -29 & -55 & 16 & -35 & -18 \\
\hline Other investment balance & 81 & 266 & 76 & 172 & 124 \\
\hline Loans provided to N.A. & 16 & 94 & 73 & 47 & 90 \\
\hline Repayments on loans extended to N.A. & 55 & 84 & 38 & 43 & 82 \\
\hline $\begin{array}{l}\text { Change in reserves } \\
\text { (-sign means increase) }\end{array}$ & -108 & 96 & -50 & -135 & 15 \\
\hline Financial account balance & -59 & 319 & 71 & 15 & 138 \\
\hline
\end{tabular}

Source: Data provided by the Antillean authorities. 
Table 24. Netherlands Antilles: Flow of Development Aid, 1992-m98

(In millions of NA guilders)

\begin{tabular}{|c|c|c|c|c|c|c|c|}
\hline & 1992 & 1993 & 1994 & 1995 & 1996 & 1997 & 1998 \\
\hline Multi-year plan & 60.0 & 94.1 & 83.9 & 84.5 & 112.4 & 115.9 & 96.6 \\
\hline $\begin{array}{l}\text { Fund for social, educational, } \\
\text { and cultural projects }\end{array}$ & 11.1 & 5.6 & 2.2 & 4.6 & 8.1 & 8.6 & 7.2 \\
\hline European Development Fund & 7.5 & 8.0 & 11.4 & 5.6 & 8.1 & 3.7 & -- \\
\hline Total & 78.6 & 107.7 & 97.5 & 94.7 & 128.6 & 128.2 & 103.8 \\
\hline
\end{tabular}

Source: Data provided by the Antillean authorities. 
Table 25. Netherlands Antilles: Multi-Year Plan Disbursements by Sectors and Authorities, 1992-98

( In millions of NA guilders)

\begin{tabular}{|c|c|c|c|c|c|c|c|}
\hline & 1992 & 1993 & 1994 & 1995 & 1996 & 1997 & 1998 \\
\hline Public utilities & 7.4 & 13.8 & 9.9 & 2.5 & 0.0 & 0.0 & 0.0 \\
\hline Airports & 1.1 & 3.1 & 3.2 & 0.6 & 0.0 & 0.0 & 0.0 \\
\hline Harbors & 2.3 & 13.6 & 4.1 & 1.1 & 0.0 & 0.0 & 0.0 \\
\hline Roads and bridges & 0.9 & 1.3 & 2.4 & 7.9 & 9.7 & 22.6 & 13.4 \\
\hline Education & 6.5 & 21.4 & 19.4 & 17.6 & 26.9 & 26.7 & 27.7 \\
\hline Health & 8.8 & 3.8 & 1.8 & 3.4 & 6.3 & 18.7 & 25.8 \\
\hline Housing & 5,2 & 16.6 & 25.3 & 17.3 & 29.7 & 32.0 & 12.6 \\
\hline Tourism & 3.6 & 2.6 & 1.1 & 0.6 & 0.0 & 0.0 & 0.0 \\
\hline \multicolumn{6}{|l|}{ Agriculture, animal husbandry, } & 0.0 & 0.0 \\
\hline Trade, industry and other services & 2.9 & 7.0 & 4.6 & 12.9 & 19.1 & 4.4 & 6.7 \\
\hline Various & 21.2 & 10.9 & 12.1 & 20.6 & 20.7 & 11.5 & 10.4 \\
\hline Total & 60.0 & 94.1 & 83.9 & 84.5 & 112.4 & 115.9 & 96.6 \\
\hline \multicolumn{8}{|l|}{ Of which: } \\
\hline Central Government & 4.8 & 12.9 & 11.1 & 12.8 & 15.9 & 28.1 & 23.4 \\
\hline Curaçao & 39.9 & 49.7 & 52.1 & 52.7 & 46.2 & 42.0 & 33.8 \\
\hline Bonaire & 6.3 & 13.8 & 4.1 & 8.6 & 1.6 & 1.1 & 3.5 \\
\hline Windward Islands & 9.0 & 17.7 & 6.4 & 10.4 & 48.7 & 40.9 & 29.3 \\
\hline Not classified & 0.0 & 0.0 & 10.2 & 0.0 & 0.0 & 3.8 & 6.6 \\
\hline Total & 60.0 & 94.1 & 83.9 & 84.5 & 112.4 & 115.9 & 96.6 \\
\hline
\end{tabular}

Source: Data provided by the Antillean authorities. 
Table 26. Netherlands Antilles: Aid from the European Development

Fund, Disbursements by Sectors and Authorities, 1990-97

( In millions of NA guilders)

\begin{tabular}{|c|c|c|c|c|c|c|c|c|}
\hline & 1990 & 1991 & 1992 & 1993 & 1994 & 1995 & 1996 & 1997 \\
\hline Public utilities & 7.0 & 0.0 & 0.0 & 0.0 & 0.0 & 0.0 & 0.0 & 0.0 \\
\hline Airports & 4.1 & 1.8 & 0.6 & 0.0 & 0.0 & 0.0 & 0.0 & 0.0 \\
\hline Harbors & 0.0 & 0.0 & 0.0 & 0.4 & 0.0 & 0.0 & 0.0 & 0.0 \\
\hline Roads & 0.0 & 0.0 & 0.9 & 0.0 & 0.0 & 0.0 & 0.0 & 0.0 \\
\hline Education & 0.0 & 0.1 & 0.1 & 0.0 & 0.1 & 0.1 & 0.8 & 0.4 \\
\hline Tourism & 0.3 & 7.7 & 3.2 & 6.6 & 5.3 & 5.0 & 4.1 & 2.3 \\
\hline Various & 0.8 & 5.9 & 2.7 & 1.0 & 6.0 & 0.5 & 3.2 & 1.0 \\
\hline Total & 12.2 & 15.5 & 7.5 & 8.0 & 11.4 & 5.6 & 8.1 & 3.7 \\
\hline \multicolumn{9}{|l|}{ Of which: } \\
\hline Central government & 0.8 & 1.3 & 0.8 & 0.5 & 2.8 & 0.6 & 1.0 & 0.2 \\
\hline Curaçao & 7.1 & 3.9 & 3.5 & 5.0 & 6.8 & 2.7 & 4.2 & 1.8 \\
\hline Bonaire & 0.0 & 7.2 & 0.8 & 0.7 & 0.9 & 1.4 & 1.2 & 0.5 \\
\hline Windward Islands & 4.3 & 3.1 & 2.4 & 1.8 & 0.9 & 0.9 & 1.7 & 1.2 \\
\hline
\end{tabular}

Source: Data provided by the Antillean authorities. 
Table 27. Netherlands Antilles: Net International Reserves, 1994-2000

(In millions of NA guilders, End of Period)

\begin{tabular}{|c|c|c|c|c|c|c|c|}
\hline & 1994 & 1995 & 1996 & 1997 & 1998 & 1999 & 2000 \\
\hline Net international reserves $\mathrm{V}$ & 468.6 & 718.0 & 602.4 & 652.1 & 777.7 & 762.9 & 636.3 \\
\hline Excluding gold & 401.1 & 509.2 & 412.9 & 462.6 & 597.9 & 583.1 & 497.4 \\
\hline Central bank & 388.2 & 625.3 & 527.8 & 576,4 & 623.4 & 654.2 & 605.5 \\
\hline Foreign currency & 367,7 & 474.5 & 357.0 & 402 & 446.1 & 475.3 & 469.7 \\
\hline Gold & 67.5 & 208.8 & 189.5 & 189.5 & 179.8 & 179.8 & 138.9 \\
\hline Short-term liabilitics & 47.0 & 58.0 & 18.7 & 15.1 & 2.5 & 0.9 & 3.1 \\
\hline Commerçial banks, net & 80.4 & 92.7 & 74.6 & 75.7 & 154.3 & 108.7 & 30.8 \\
\hline Assets & $1,370.0$ & 791.7 & 793.7 & 777.2 & 926.5 & 922.3 & 987.5 \\
\hline Liabilities & $1,289.6$ & 699.0 & 719.1 & 701.5 & 772.2 & 813.6 & 956.7 \\
\hline
\end{tabular}

Source: Data provided by the Antillean authorities.

1/ Includes revaluation of gold of NA f. 141.3 million in 1995, NA f. -19.3 million in 1996, NA f. -0.5 million in 1997 , NA f. -9.2 million in November 1998, and NA f. -40.9 million in December 2000. 